\title{
HYDROLOGIC RECONNAISSANCE OF THE
}

\section{Chilkat River}

Basing

\section{SOUTHEAST ALASKA}

With Special Reference to the Alaska Chilkat Bald Eagle Preserve

By Edward F Bugliosi

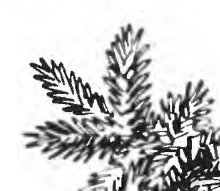

Prepared in cooperation with the

ALASKA DEPARTMENT OF NATURAL RESOURCES DIVISION OF GEOLOGICAL AND GEOPHYSICAL SURVEYS
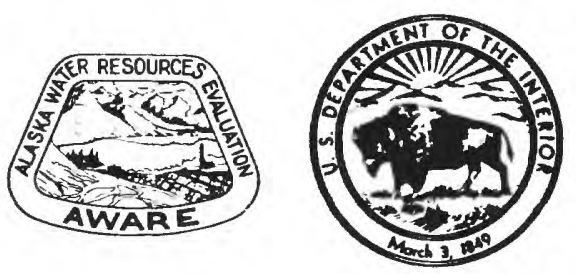

ANCHORAGE, ALASKA

1988 
DEPARTMENT OF THE INTERIOR

DONALD PAUL HODEI, SECRETARY

U.S. GEOLOGICAL SURVEY

Dallas L. Peck, D1rector

For additional information write to:

District Chief

U.S. Geological Survey

Water Resources Division

4230 University Drive, Suite 201

Anchorage, Alaska 99508-4664
Copies of this report can be purchased from:

U.S. Geological Survey

Books and Open-File Reports Section Federal Center

Box 25425

Denver, Colorado 80225 


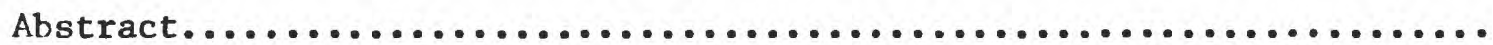

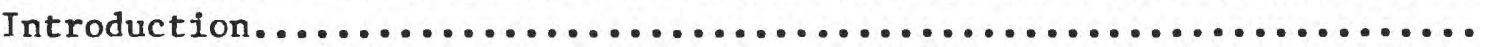

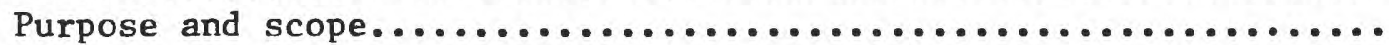

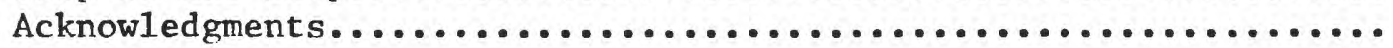

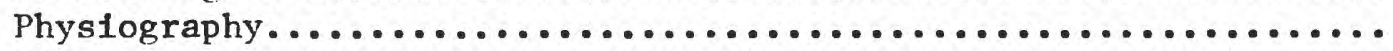

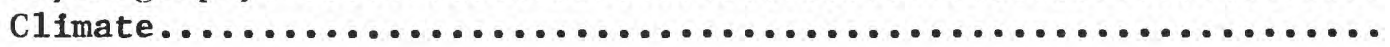

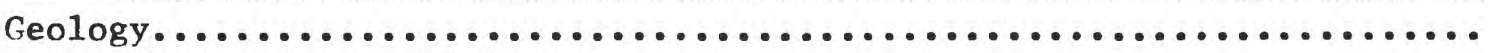

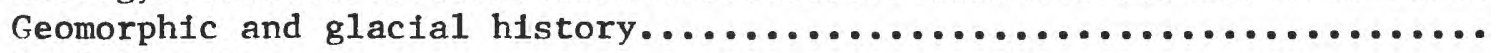

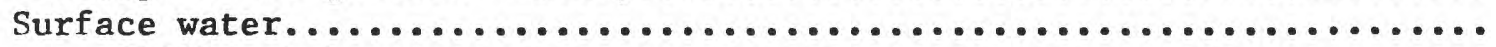

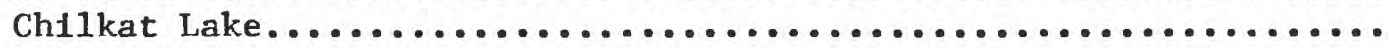

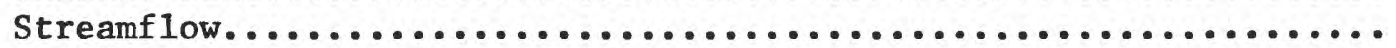

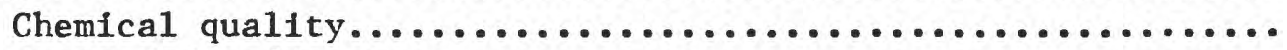

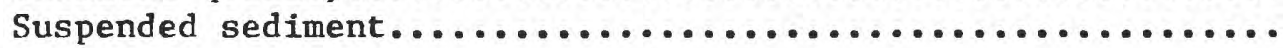

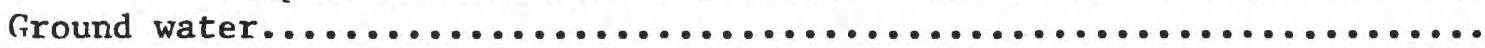

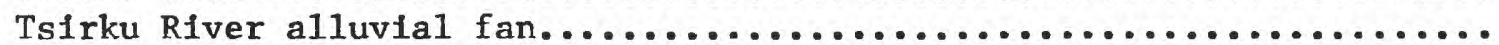

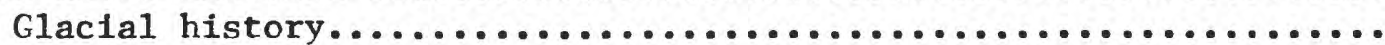

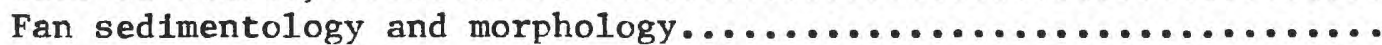

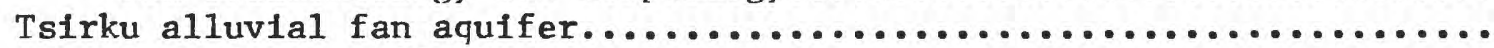

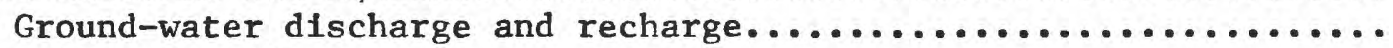

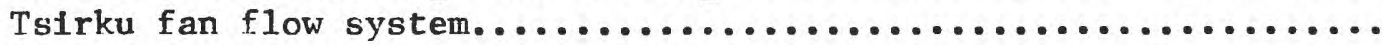

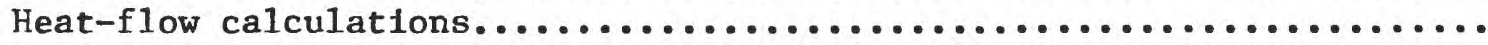

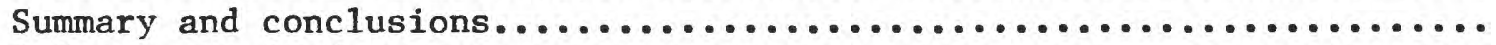

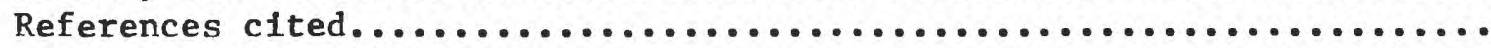

\section{ILLUSTRATIONS}

Figure 1. Map showing location of study area...................

2. Map of Chilkat River basin, major subbasins, and locations

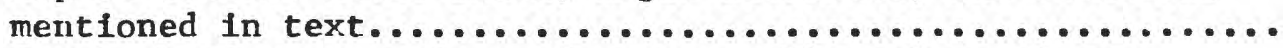

3. Graph showing comparison of mean monthly values of precipitation and temperature for Haines and Klukwan, 1927-1943.

4. Map of surficial geology of Tsirku alluvial fan area near

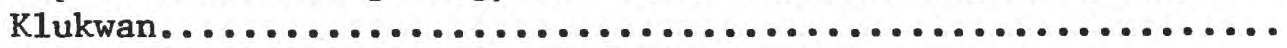

5. Schematic geologic section of Tsirku alluvial fan area near

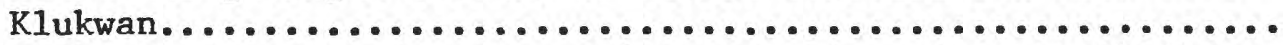

6. Bathymetric map and water-qualfty sampling sites at ChIlkat

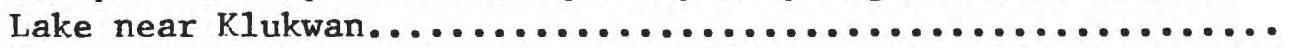

7. Graphs showing temperature, specific conductance, $\mathrm{pH}$, and dissolved-oxygen profiles of Chilkat Lake.................

8. Diagrams showing percentage composition of maior cations and anions, and dissolved-solids concentration for Chllkat Lake

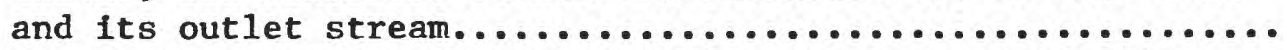

9. Map showing continuous-record gaging station and miscellaneous measurement sites in the Chilkat River basin..........

10. Hydrograph for Klehini River, October 1981 to September 1982.

11. Graph showing discharge relation between Klehini and Tsirku

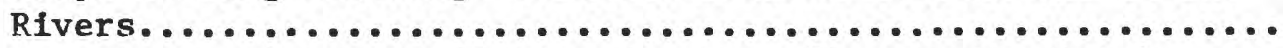

12. Map showing losses and gains in streamflow in the Tsirku River alluvial fan area, April 6, 1982................ 


\section{ILLUSTRATIONS -- Continued}

13. Map of surface-water quality sites In Chilkat River basin, percentage of major cations and anions, and total hardness...

14. Graph showing suspended-sediment discharge versus stream discharge for Chilkat, Klehini, and Tsirku Rivers at highand low-flow periods................................. showing bedrock depth from seismic refraction and gravimetric

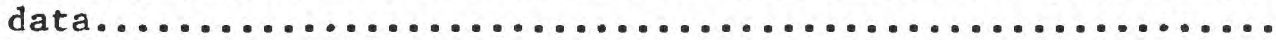

16. Map showing ground-water-quality sites on and near the Tsirku alluvial fan, percentage of major cations and anions, and

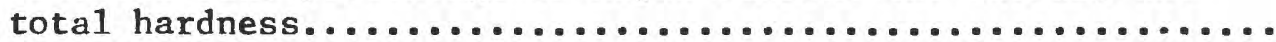

17. Map of Tsirku alluvial fan and vicinity, locations of observation wells and hydrogen-oxygen isotope sampling

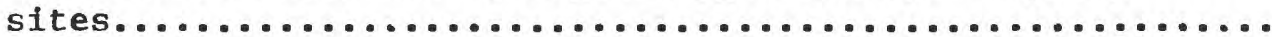

18. Photograph of Tsirku alluvial fan, October $5,1981 \ldots \ldots \ldots \ldots$.

19. Hydrograph of observation we 11 s $A R-3$ and AR-4 at the toe of the Tsirku alluvial fan showing relation between potentiometric surface in deep and shallow ground-water systems........

20. Hydrographs of observation wells on the Tsirku alluvial fan..

21. Potentiometric surface maps of shallow ground-water systems and direction of ground-water movement, Tsirku alluvial fan:

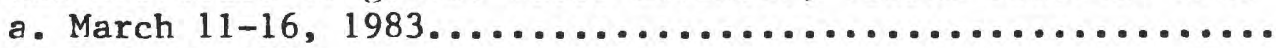

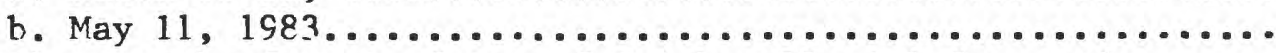

22. Photograph of part of toe of Tsirku alluvial fan, and

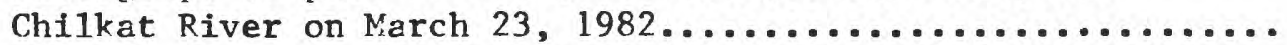

23. Photograph of Ts1rku alluvial fan, March 22, 1982.........

24. Photograph of Tsirku alluvial fan, Iune $6,1981 \ldots \ldots \ldots \ldots \ldots$.

25. Block dlagram of Tsirku River alluvial fan and vicinity, showing elements of the flow system..................

\section{TABLES}

Table 1. Percentage ice cover in the major subbasins within the

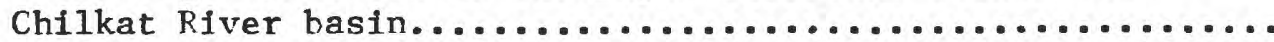

2. Surface-water quality data for selected sites in the Chilkat

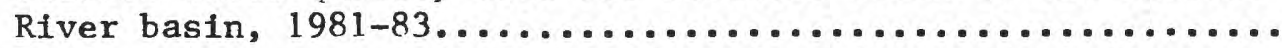

3. Drainage area, period of record, and maximum and minimum discharge for selected streams measured in the Chilkat River

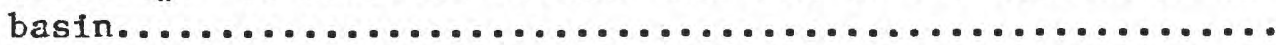

4. Monthly mean flow for Klehini and Tsirku Rivers, 1982 water

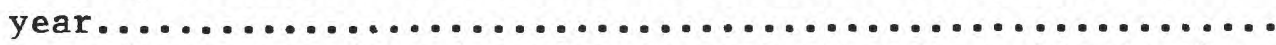

5. Ground-water quality data for four observation wells in the

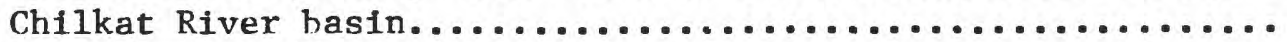

6. Oxygen and hydrogen isotope data from samples collected at selected surface-water sttes and observation wells.......... 


\section{CONVERSION FACTORS}

For use of readers who prefer to use metric (International System) units, rather than inch-pound units, the conversion factors for the terms used in this report are listed below:

Mult1ply inch-pound unit

Inch (in.)

foot $(\mathrm{ft})$

mile (mi)

square foot $\left(\mathrm{ft}^{2}\right)$

square mile $\left(\mathrm{ml}^{2}\right)$

foot per mile $(\mathrm{ft} / \mathrm{ml})$

cubic foot per second $\left(\mathrm{ft}^{3} / \mathrm{s}\right)$

ton, short, per day (ton/d)

degree Fahrenheft $\left({ }^{\circ} \mathrm{F}\right)$
By

$$
25.4
$$

0.3048

1.609

0.09294

2.590

0.1894

0.02832

0.9072

${ }^{\circ} \mathrm{C}=5 / 9\left({ }^{\circ} \mathrm{F}-32\right)$
To obtain metric unit

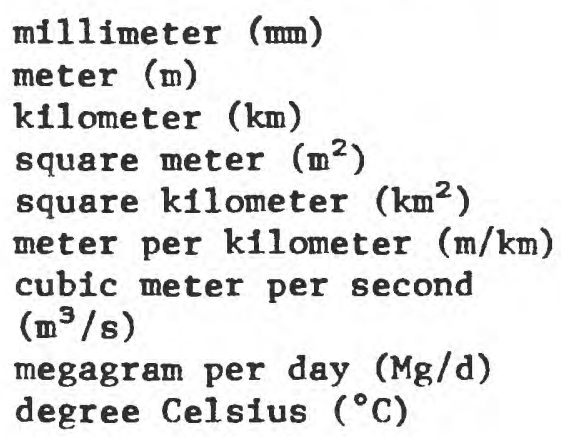

Other abbreviations in this report are:

$\mu \mathrm{S} / \mathrm{cm}$, microsiemens per centimeter at $25{ }^{\circ} \mathrm{C}$ $\mathrm{mg} / \mathrm{L}$, milligram per 11ter

$\mu g / L$, microgram per liter

NTU, nephelometric turbidity unit

Sea level:

In this report "sea level" refers to the National Geodet1c Vertical Datum of 1929 (NGVD of 1929) -- a geodetic datum derived from a general adjustment of the first-order level nets of both the United States and Canada, formerly called "Mean Sea Level of 1929." 
HYDROLOGIC RECONNAISSANCE OF THE CHILKAT RIVER BASIN, SOUTHEAST ALASKA

With Special Reference to the Alaska Chilkat Rald Eagle Preserve

By Edward F. Bugliosi

\section{ABSTRACT}

The Chilkat River basin in southeast Alaska is characterized by rugged, highly dissected mountains with steep-gradient streams, braided rivers in broad alluviumfilled valleys, and numerous glaclers. A wide seasonal range in temperature and strong orographic effects cause variations in the amount and distribution of precipitation, and thus in the resulting runoff and streamflow. Streamflow is lowest in winter, when precipitation at higher altitudes is stored as snow, and greatest in summer, when melting snow and glacier ice augment flow. Ground-water seeps and springs flowing from alluvial fans contribute to streamflow year round.

A ground-water discharge zone of particular interest is that along the toe of the Tsirku River alluvial fan, 20 miles north of Haines. During winter, the relatively warm ( 4 to 6 degrees Celsius) ground water maintains open leads in a reach of the Chilkat River downstream from the fan. This ice-free reach provides favorable spawning habitat for a late run of chum and coho (silver) salmon, which in turn attracts the world's largest concentration of bald eagles (more than 3,000 birds). The principal source of recharge to the ground-water system in the fan is infiltration from the Tsirku River.

Surface and ground waters are chemically similar, calcium bicarbonate types. A11 stream samples had dissolved-solids concentrations of less than 115 milligrams per liter; values for ground water were slightly greater. During high summer flows, the suspended-sediment concentrations of the glacially fed Chilkat, Tsirku, and Klehini Rivers ranged from 361 to 1,530 milligrams per 1 iter $(6,360$ to 22,300 tons per day).

\section{INTRODUCTION}

The Chilkat River basin, at the head of Lynn Canal about $80 \mathrm{mi}$ northwest of Juneau in southeast Alaska ( $f$ ig. 1), is bordered by the Takhinsha Mountains and Glacier Bay National Park and Preserve to the south and by the Takshanuk Mountains to the east (fig. 2). The northern and western parts of the hasin lie within British Columbia, Canada.

The area around the toe of the alluvial fan at the mouth of the Tsirku River, which enters the Chilkat River near the community of Klukwan, is the site of the largest known concentration of bald eagles in the world (Boeker and others, 1980) and has been designated the Alaska Chilkat Bald Eagle Preserve. As many as 3,000 eagles are attracted each year by the late-fall to early-winter runs of chum and coho (silver) salmon up the Chilkat River. The spawned-out salmon provide the 


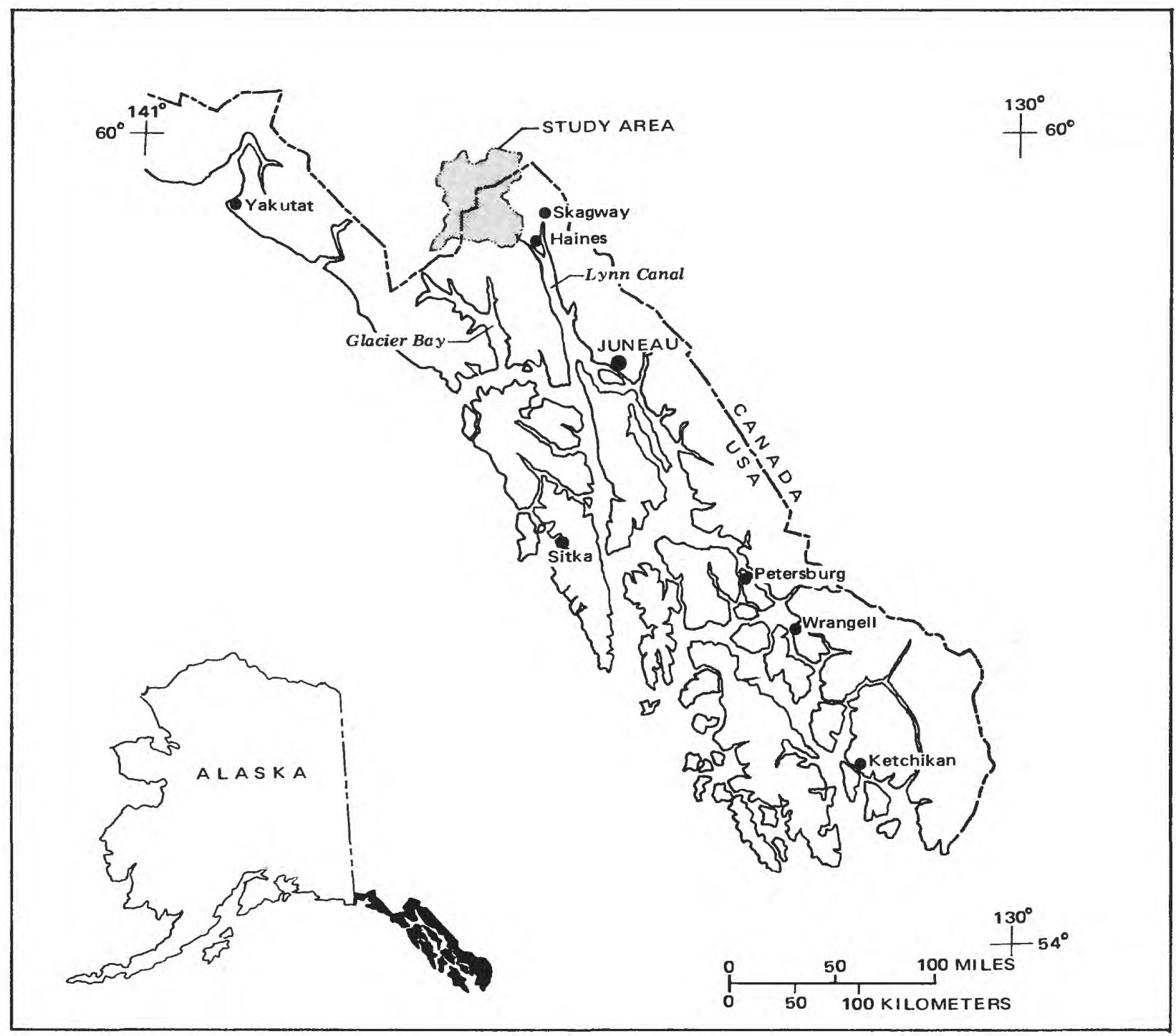

Figure 1. -- Location of study area.

birds with an abundant food source during the winter months because much of the Chilkat River at the toe of the Tsirku River fan remains free of ice.

Hydrologic investigations were begun in the Chilkat-Tsirku Rivers area by D.M. Bishop (1980) in response to concerns of State and Federal wildlife agencies and the National Audubon Society that potential mining and logging activities in the area might affect the hydrologic system and consecuently the salmon-eagle relationship. The II.S. Geological Survey began its hydrologic study of the area in May 1981 under a cooperative funding agreement with the Alaska Department of Natural Resources, Division of Geological and Geophysical Surveys (DGGS). The DGGS also drilled the water-level observation wells on the Tsirku River alluvial fan, and continues to share costs with Geological Survey to operate the stream-gaging station established on the Klehini River as part of the study. 


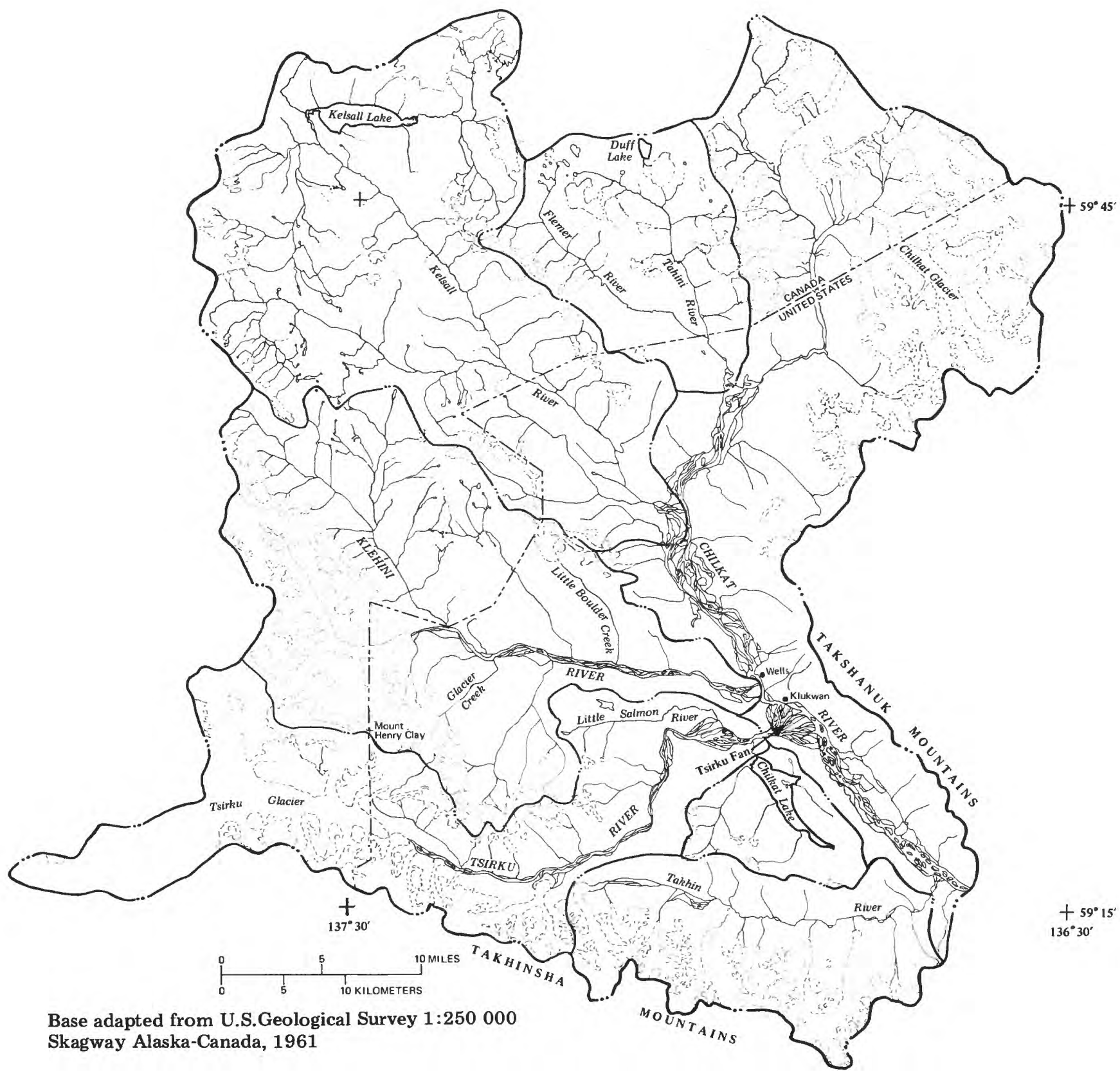

Figure 2. -- Chilkat River basin, major subbasins, and locations mentioned in text. 


\section{Purpose and Scope}

The objectives of this study were to (1) describe the general geology and hydrology of the Chilkat River basin, and (2) determine the relation between surface water and the ground water in the vicinity of the Tsirku River alluvial fan. The information compiled and data collected as part of the study are presented and discussed in this report.

\section{Acknowledgements}

The author wishes to thank Larry Dearborn (then hydrologist with DGGS) for geophysical logging of the observation wells, and for his suggestions regarding the hydrogeology of the study area. Dearborn and DGGS hydrologist James Munter also provided technical review of an early draft of this report. Thanks are also due the people of Haines and the Chilkat River valley for their cooperation and assistance in the conduct of the study. I also wish to acknowledge the cooperation of, and information from, the staff of the National Audubon Society in Alaska.

\section{Physiography}

The Chilkat River basin (about $1,000 \mathrm{mi}^{2}$ ), is characterized by rugged, highly dissected mountains with steep-gradient streams; braided rivers in broad, glaciated, U-shaped valleys; and numerous glaclers (fig. 2). Altitudes range from sea level at the mouth of Chilkat River to $7,434 \mathrm{ft}$ at the summit of Mount Henry Clay. Areas below timberline (about 2,000 ft altitude) support dense brush and forests of spruce and hemlock.

\section{Climate}

The climate is typified by moderate summers and moderately mild winters with heavy snowfall. Weather conditions, especially precipitation, change within short distances owing to local orographic, glacial, and oceanic effects. Mean annual precipitation at Haines is $65 \mathrm{in.,} \mathrm{compared} \mathrm{with} 20 \mathrm{in}$. at Klukwan. Mean annual temperature also decreases from 40 to $36^{\circ} \mathrm{F}$ between Haines and klukwan (Johnson and Twenhofe1, 1953).

During the period May 1982 to June 1983, the temperature at Haines ranged from -12 to $92{ }^{\circ} \mathrm{F}$. It is not uncommon for simultaneous temperatures to differ by as much as $10^{\circ} \mathrm{F}$ between Haines and Klukwan, $20 \mathrm{mi}$ from each other. Precipitation also differs significantly between the two areas (fig. 3). Generally, during winter, the Tsirku alluvial fan area near Klukwan is colder and receives less precipitation than Haines.

\section{GEOLOGY}

The Chilkat River basin is divided into two distinct geologic provinces by the Chilkat River fault (which roughly parallels the Chilkat River), an extension of the Chatham Strait fault system to the south (Brew and others, 1966; Ovenshine and Brew, 1972). The geology of two $1: 63,360$ quadrangles (Skagway B-3 and B-4) has 


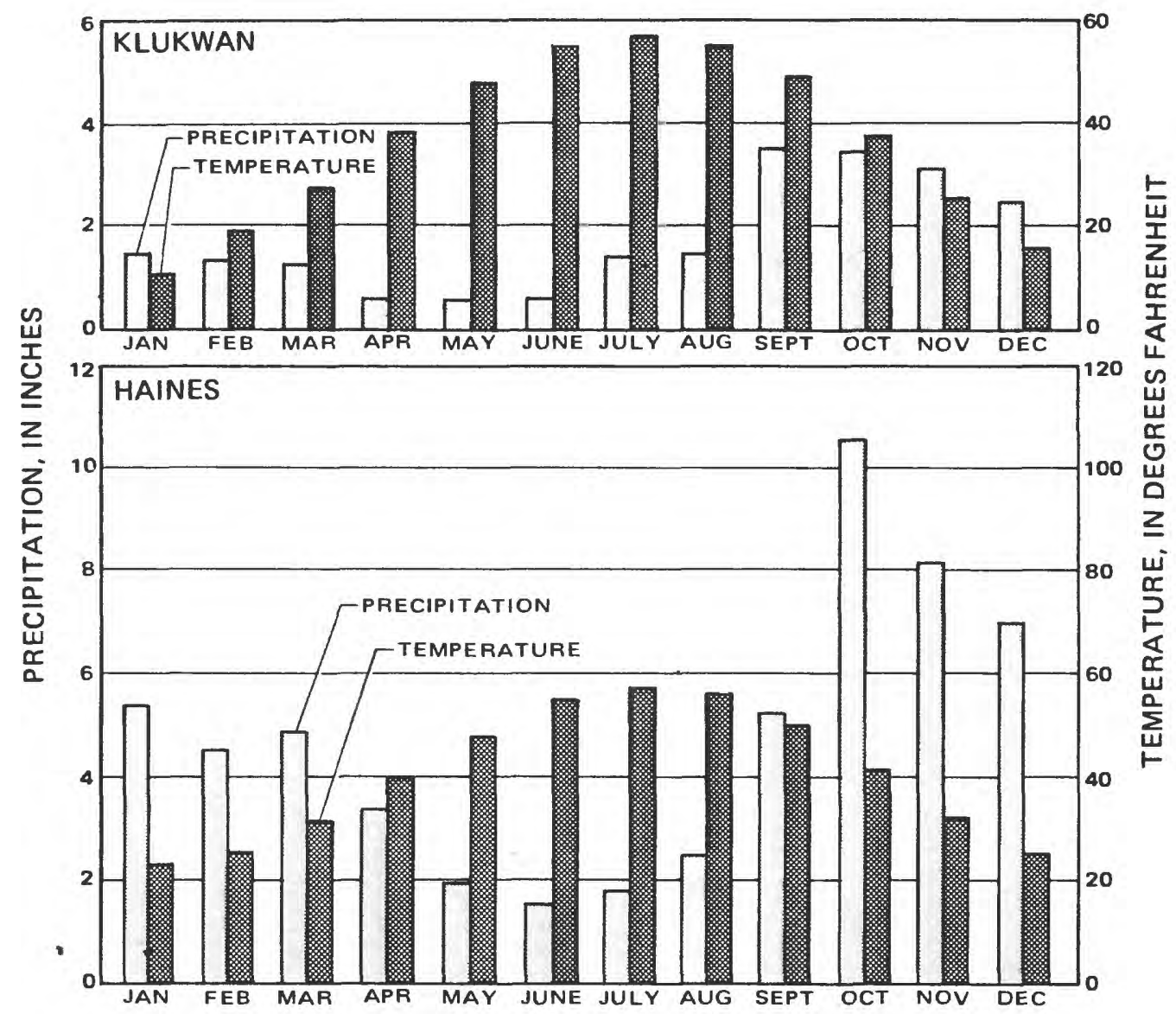

Figure 3. -- Comparison of mean monthly values of precipitation and temperature for Haines and Klukwan,1927-1943 (from Johnson and Twenhofel, 1953).

been mapped by Mackevett and others (1974). East of the fault and Chilkat River, structural trends are predominantly northwest, as in much of southeast Alaska; west of the fault and river the structural trends are complex and include west-trending faults and lineaments.

The rocks east of the Chilkat River consist of intrusives and metavolcanics that range in age from Cretaceous to early Tertiary, from about 100 to 50 million years old (figs. 4 and 5). West of the river, the basin is underlain by 1ithologically diverse, metamorphosed Paleozolc, Cretaceous, and Tertiary rocks, from 500 to 50 million years old.

\section{GEOMORPHIC AND GLACIAL HISTORY}

The geologic history of the Chilkat River basin includes periods of mountain building which began as late as Cenozolc time (60 million years ago) and presently continues (Ovenshine and Brew, 1972). This movement produced the rugged, high1y dissected mountains characteristic of the area. The principal land-shaping process in recent (Quaternary) geologic time has been glaciation, which is still dominant in the upper parts of the basin. Most types of glacial features can be found in the Chilkat River basin, including ground moraine which covers much of the bedrock at lower altitudes, espectally in the area of the Tsirku River alluvial fan. 


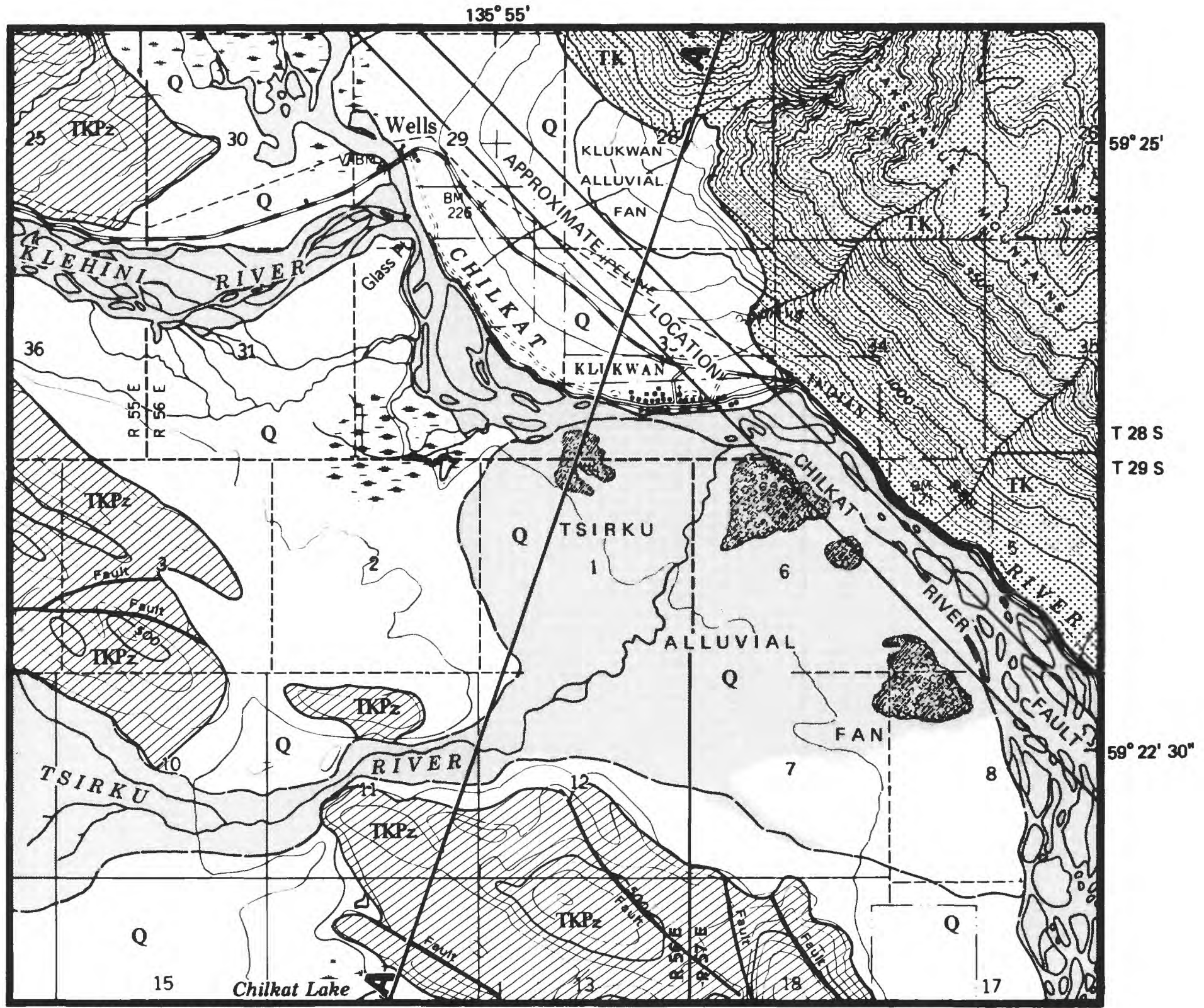

Base from U.S. Geological Survey, 1:63,360, Skagway B-3, B-4, 1954

Geology from MacKevett and others, 1974

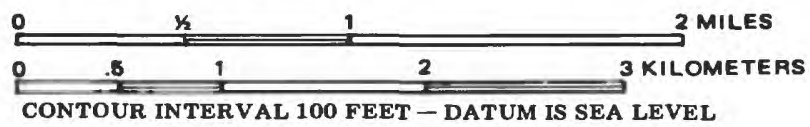

EXPLANATION

\section{Q}

UNDIVIDED SURFICIAL DEPOSITS

Include old and modern alluvium, undifferentiated glacial deposits, and colluvium of Quaternary age. Screened area approximate area flooded during summer high water.

\section{$\because \mathrm{K}$}

IGNEOUS ROCKS

Intrusive and metamorphosed volcanic rocks including metabasalts, gabbro and diorite, and mafic and felsic dikes of Tertiary and Cretaceous age. $\mathrm{A}^{\prime}$ Line of cross section (see figure 5 )

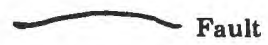

\section{The}

INTRUSIVE AND METAMORPHOSED SEDIMENTARY ROCKS

Lithologically diverse metamorphosed sedimentary rocks including marbles, schist, slate, gneiss, and various diorites of Tertiary, Cretaceous, and Paleozoic age.

Figure 4. -- Surficial geology of the Tsirku alluvial fan area near Klukwan. 


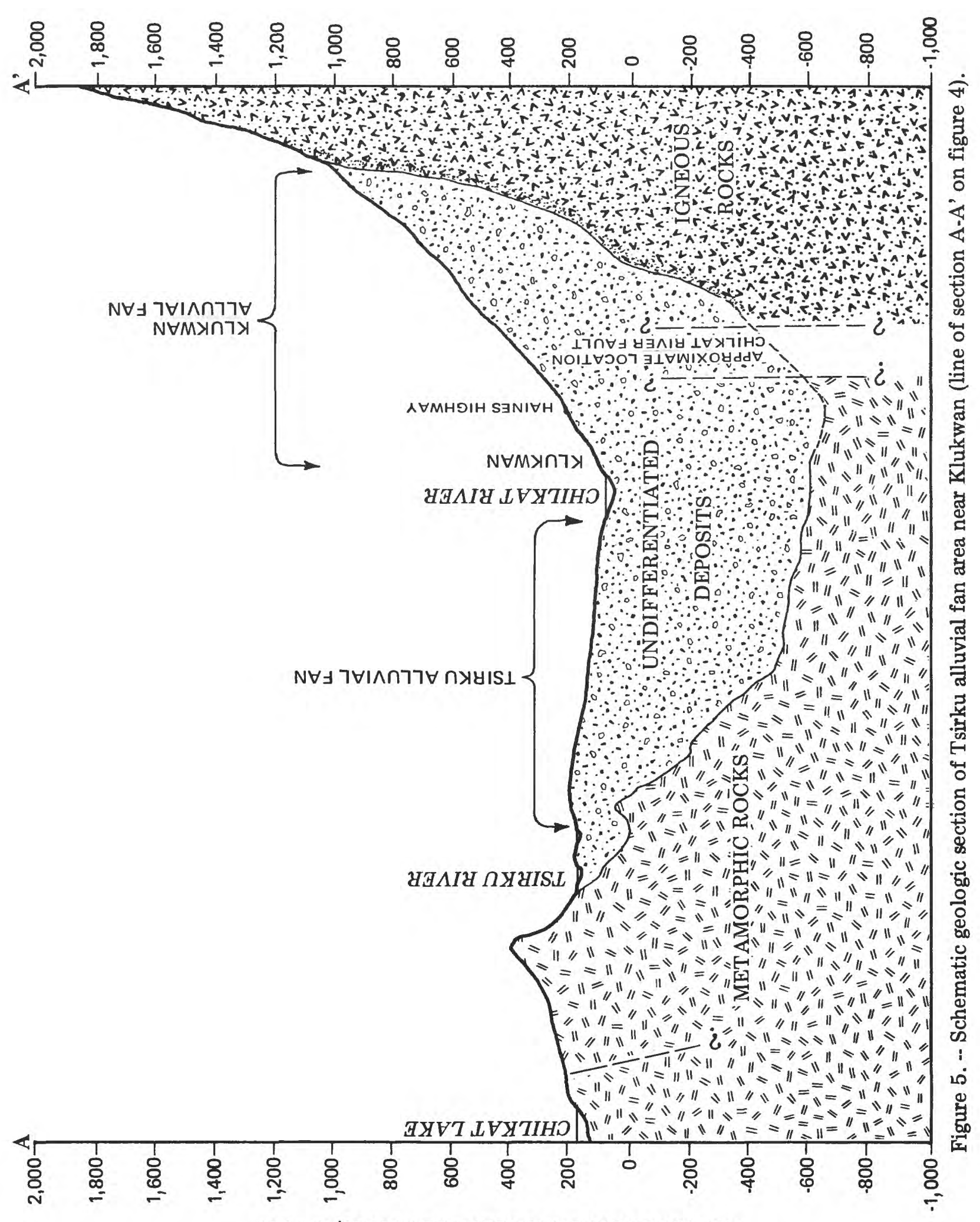

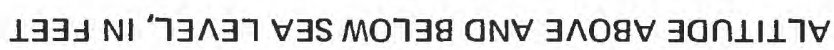


The complex glacial history includes multiple, basin-wide glaciations and local fluctuations of individual glaciers. The last advance of ice into the lower altitudes of the valleys (at least as far downvalley as the Tsirku alluvial fan) may have been as recent as about 1,700 years or as early as about 11,000 years before present (McKenzle and Goldthwalt, 1971). Multiple Wisconsin glacial fluctuations in the study area have not been defined, but the fluctuations probably paralleled those in Adams Inlet of Glacier Bay National Monument (McKenzie and Goldthwa1t, 1971).

Topographic maps compiled from aerial photographs taken in 1962 show about 25 percent of the Chilkat River basin covered by glaciers. Ice cover within the maior subbasins ranges from 5 to 37 percent (table 1). More recent observations and aerlal photographs indicate the glaciers have been retreating during the past 30 years (L. R. Mayo, U.S. Geological Survey, oral commun., 1982), so that present-day ice cover in the basin is probably less than that shown on the maps.

Table 1.--Percentage ice cover in the major subbasins within the Chilkat River basin

\begin{tabular}{lc}
\hline \multicolumn{1}{c}{ Subbasin } & $\begin{array}{c}\text { Ice cover } \\
\text { (percent) }\end{array}$ \\
\hline Chilkat Lake & 5 \\
Kelsal1 River & 5 \\
Klehini River & 22 \\
Tahini River & 10 \\
Takhin River & 37 \\
Tsirku River & 35 \\
\hline
\end{tabular}

SURFACE WATER.

\section{Chilkat Lake}

There are many glacial lakes in the Chilkat River basin, but only three--Duff, Kelsall, and Chilkat-have areas equal to or greater than $0.5 \mathrm{mi}^{2}$. Chilkat Lake, the only one of these three that lies within Alaska, occuples a glacially scoured, fault valley about $3 \mathrm{mi}$ southwest of Klukwan (fig. 2). The lake was formed by blockage at its northwest end either as the glacier that occupled the valley retreated toward the northwest, or as outwash debris from the glacier accumulated to its present altitude of about $200 \mathrm{ft}$. A former outlet at an altitude of 300 to 400 ft (sec. 17 and 19, T. 29 S., R. 57 E.; fig. 6) suggests that the present outlet was once dammed by a glacier. The older outlet has since been abandoned for the present, lower one located between the lake and the Tsirku River (fig. 6). The lake is now about $6 \mathrm{mi}$ long, $1.5 \mathrm{mi}$ at the widest spot, and has an area of about 4 $\mathrm{mi}^{2}$. The greatest measured depth was more than $200 \mathrm{ft}$.

Inflow to Chilkat Lake is derived from perennial and intermittent streams that drain an area of $43 \mathrm{mi}^{2}$, about 5 percent of which is ice covered. Some ground 


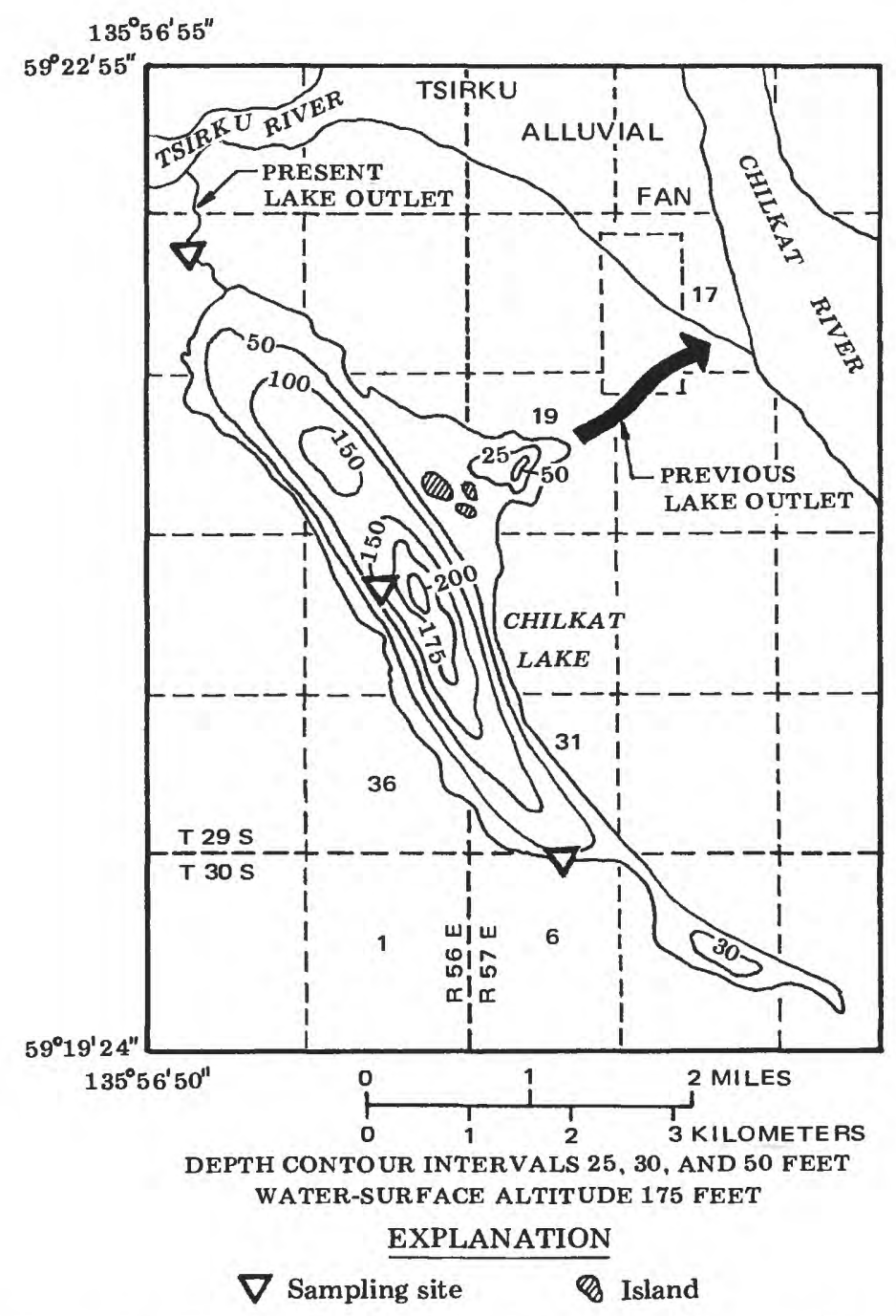

Figure 6. -- Bathymetric map and water-quality sampling sites at Chilkat Lake near Klukwan.

water flows to the lake from the highly fractured bedrock and numerous faults in the area. No direct measurements of such inflow have been made. Outflow is primarily via a stream to the Tsirku River. Discharge at the lake outlet, measured at both high- and low-flow conditions, was $304 \mathrm{ft}^{3} / \mathrm{s}$ on August 18, 1981 and $27 \mathrm{ft}^{3} / \mathrm{s}$ on April 6, 1982.

Vertical profiles of temperature, specific conductance, $\mathrm{pH}$, and dissolvedoxygen concentration were measured at a site (fig. 6) on Chilkat Lake on August 18, 1981 and March 15, 1983 ( $\mathrm{fig} .7$ ). Two samples were collected on each date, one at midepilimnion (20 to $25 \mathrm{ft}$ ) and one at mid-hypolimnjon (100 to 125 ft). Samples were analyzed for major inorganic constituents, nutrients, selected trace metals, and total organic carbon (table 2).

The calclum bicarbonate water of Chilkat Lake differs only slightly in chemical makeup between the epilimnion and hypolimnion ( $f f g .8$ ). The waters of the lake and of a major stream entering the southern end of the lake are chemically similar (table 2). The higher concentration of dissolved solids at the outlet of the lake on April 6, 1982 ( $f 1 g .8$ ) probably reflects the increase in relative 


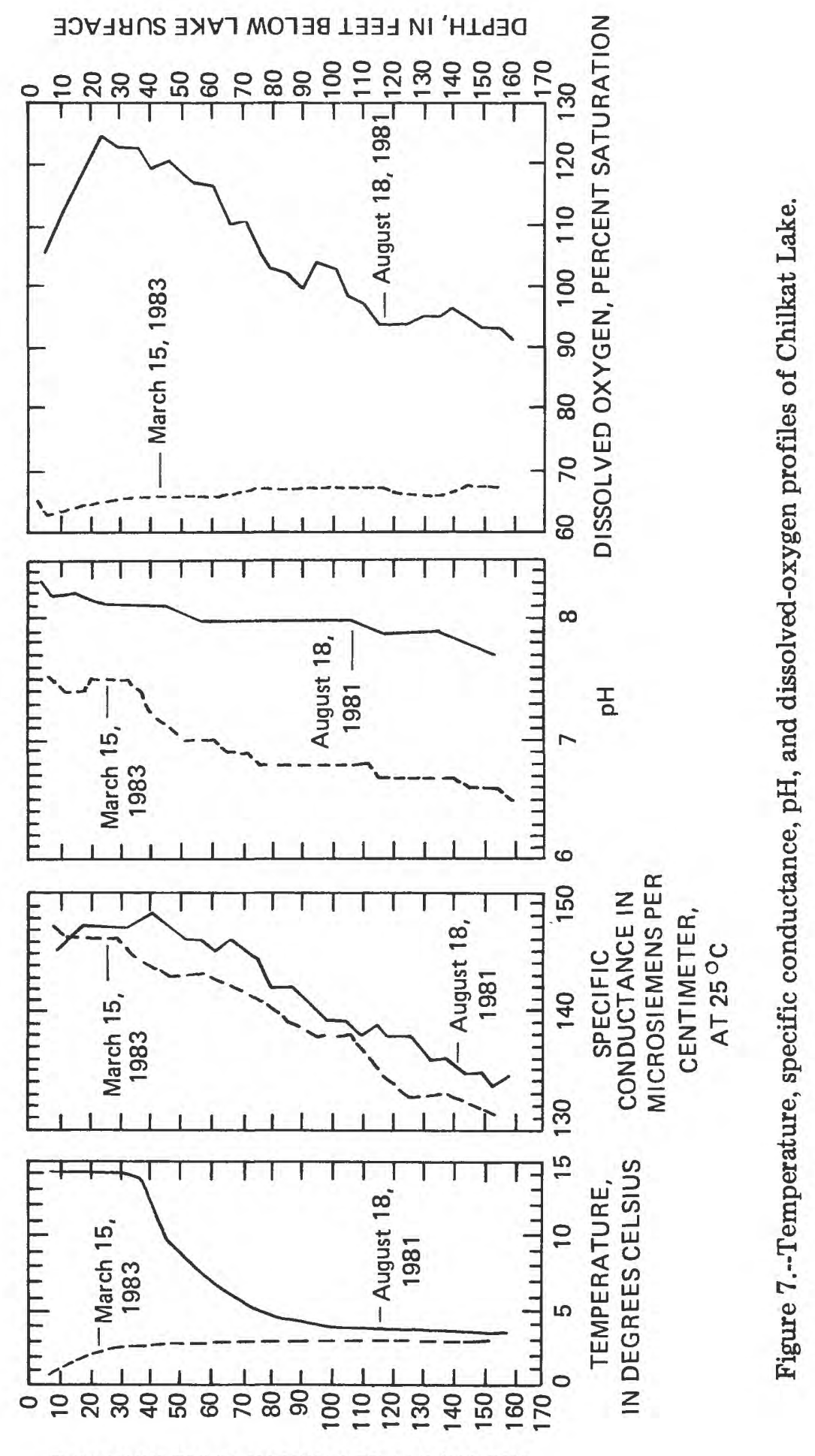

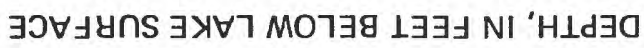




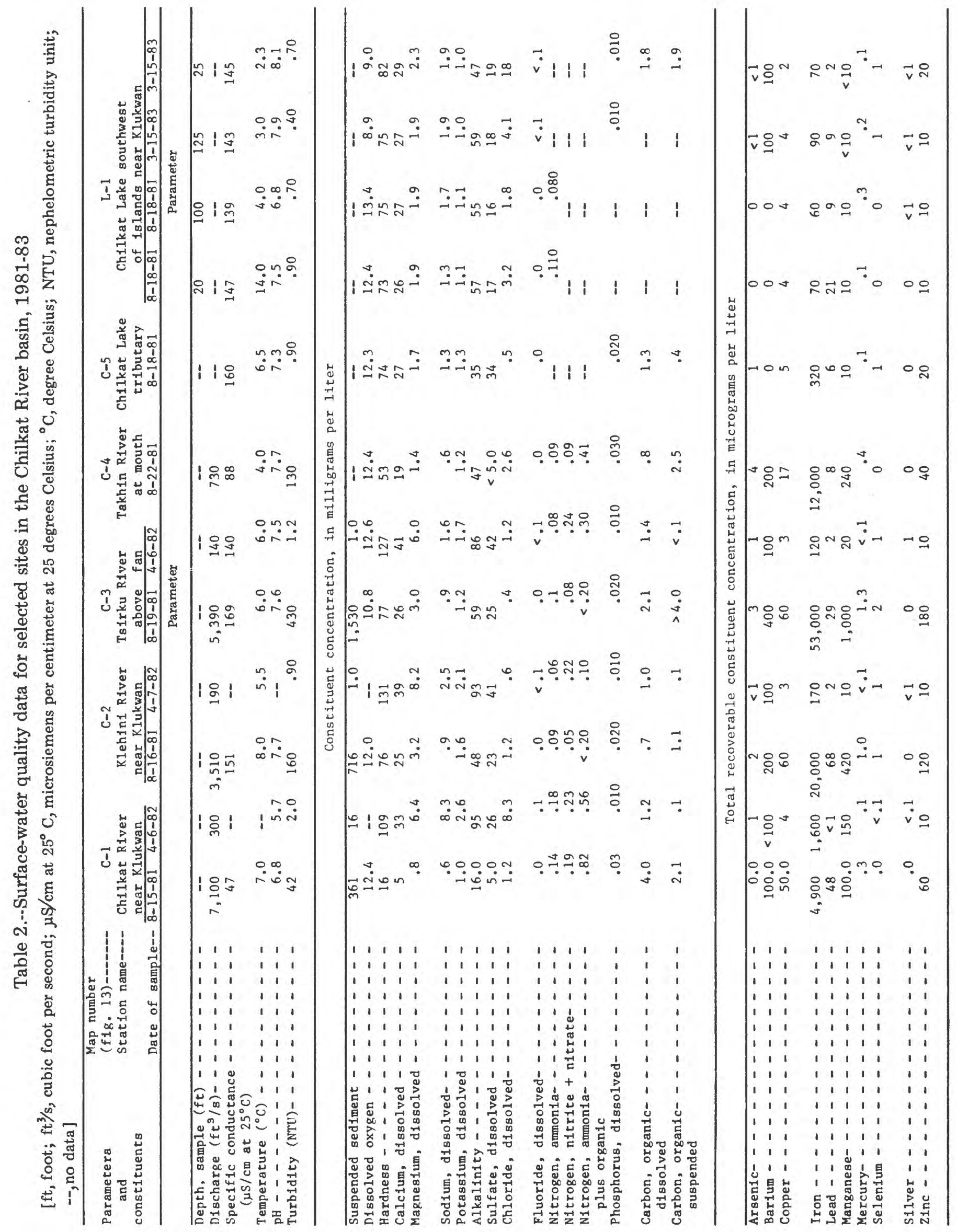




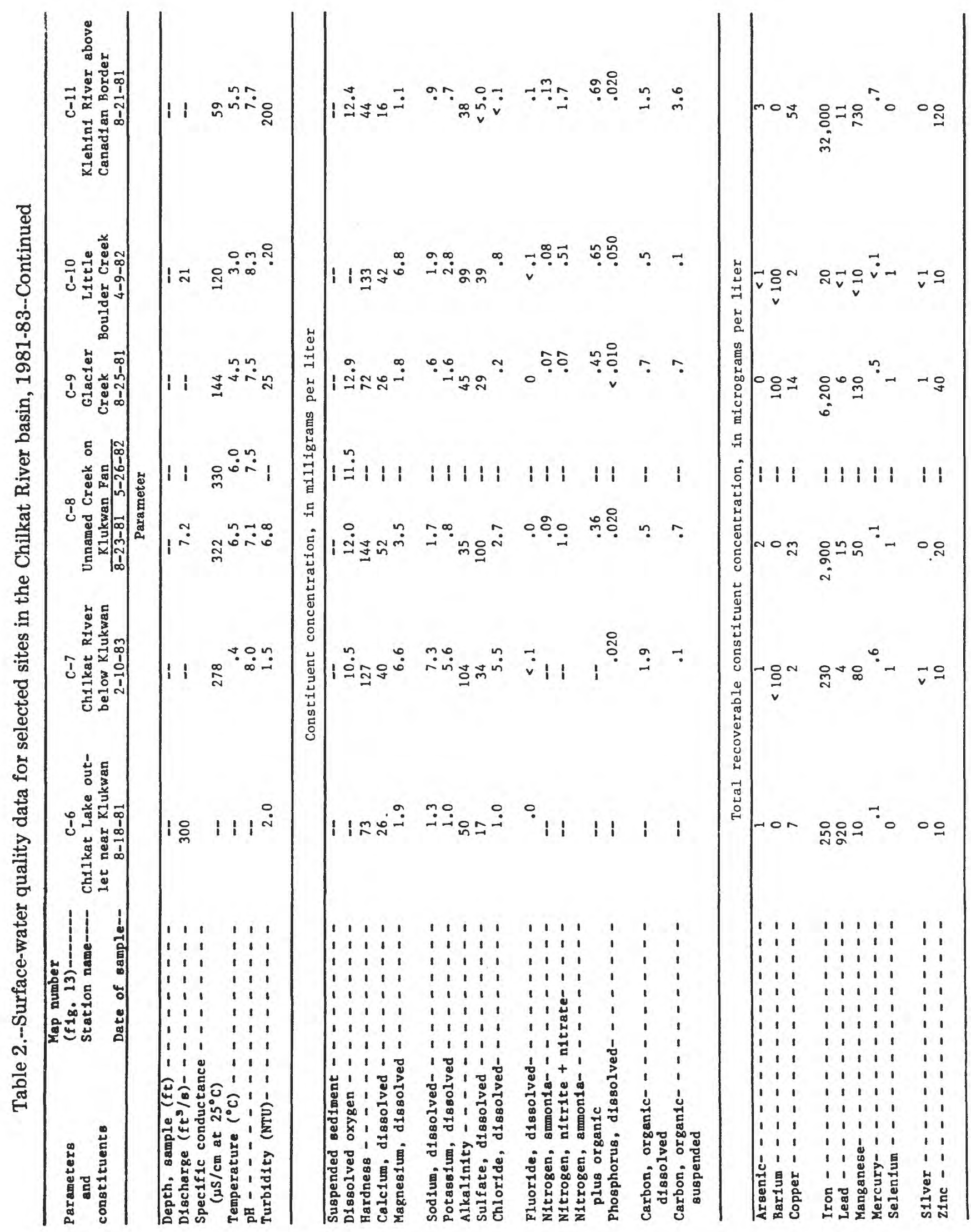


EXPLANATION

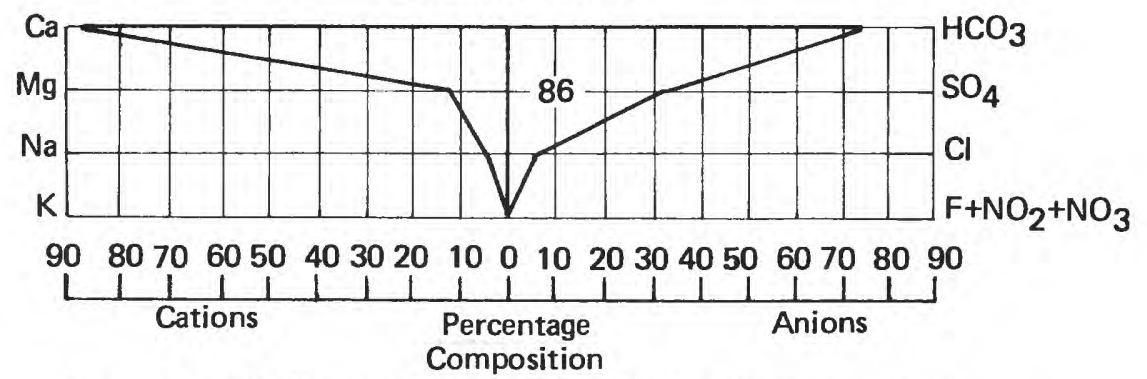

Number inside diagram represents dissolved solids concentration in milligrams per liter

CHILKAT LAKE OUTLET
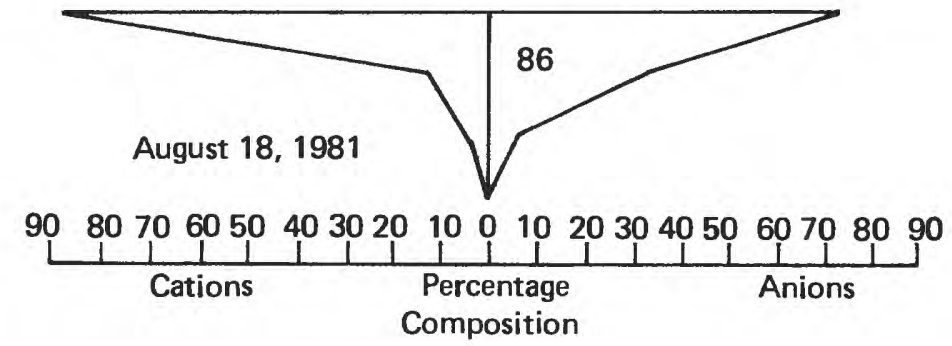

\section{CHILKAT LAKE}

EPILIMNION
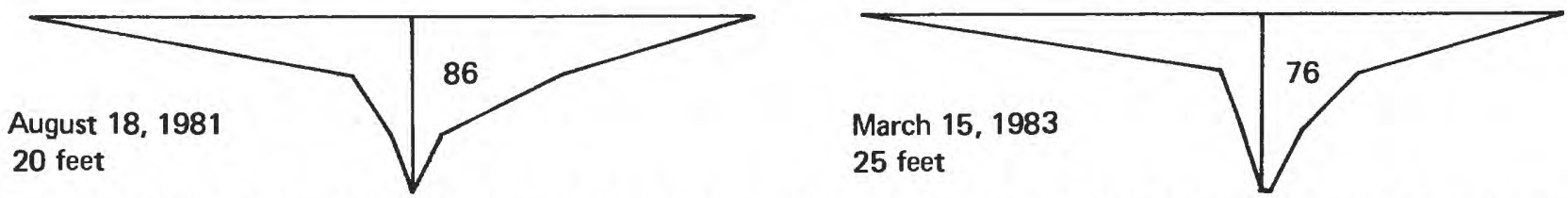

$908070605040302010 \quad 0 \quad 102030405060708090908070605040302010 \quad 0 \quad 102030405060708090$

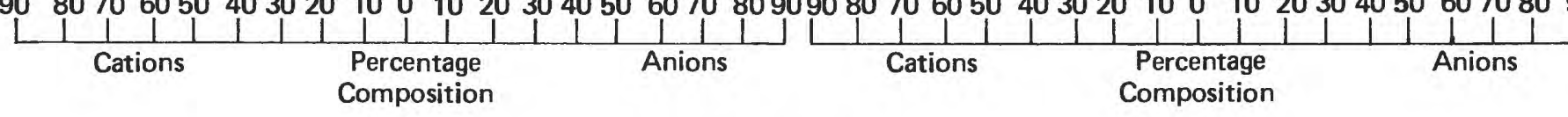

HYPOLIMNION
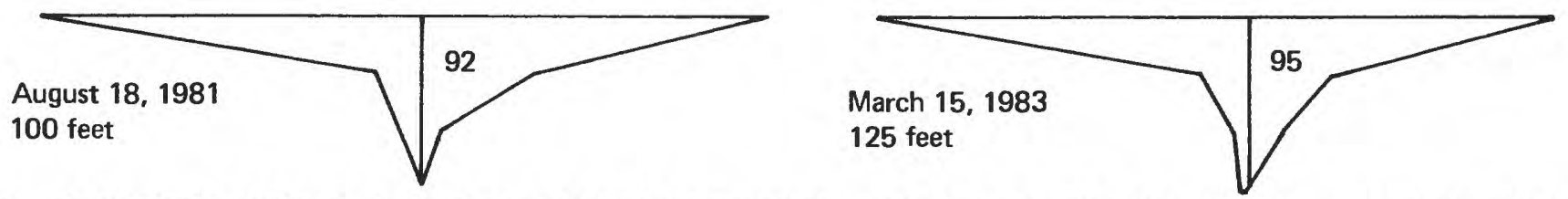

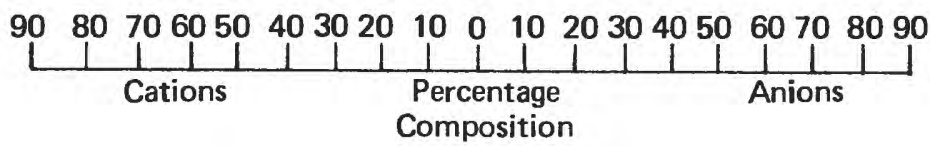

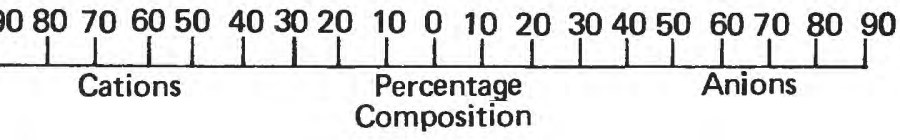

Figure 8.--Percentage composition of major cations and anions, and dissolved-solids concentration for Chilkat Lake and its outlet stream. 
amounts of ground-water discharge to that area during the winter low-flow period (see section "Tsirku Fan Flow System"). The depth profiles indicate that on August 18,1981 , the lake was thermally stratified at about $35 \mathrm{ft}$ below the water surface. Because of the similarity of the epilimnion and hypolimnion water quality and thermal stratification, it appears that the lake experienced at least one complete mixing cycle that year. Such mixing probably occurs yeariy.

Flooding of Tsirku River into Chilkat Lake has occurred several times in recent years. During periods of high flow, a branch of the Tsirku River may overtop 1ts bank, flow through the flat tree- and marsh-covered area at the northwest end of the lake and discharge into the lake. This phenomenon, which occurred in 1981, has been afded recently by an abandoned afrplane runway that channels water from Tsirku River toward Chilkat Lake. The flood waters carry high concentrations of suspended sediment, mostly silt and clay, that could affect salmon spawning areas in the lake. Fisheries biologists generally agree that excessive amounts of fine sediments in spawning gravels increase salmonid embryo and larval mortality (Shirazi and Seim, 1981).

\section{Streamf 1ow}

Streamflow in the Chilkat River basin originates as runoff from precipitation (rain or melting snow and $1 c e$ ) and as ground water discharged to the streams from springs and seeps along or in riverbeds. Runoff from melting glacier snow and ice augments streamflow during summer months. The volume of runoff in any given area is a function of precipitation, amount of snow and ice melt, size and surficial geology of the drainage area and the amount of evaporation and plant transpiration (evapotranspiration). Because of the relatively high humidity and cloudiness in much of the Chilkat River basin throughout the summer, evaporation is probably less significant than the other determinants of runoff. Ground-water discharge from seeps and springs contributes a large part of the flow of many streams during winter low-flow periods.

Streamflow measurements were made in periods of high and low flow at selected sites on the Chilkat River and on most of its maior tributaries, including the Takhin, Klehini, and Tsirku Rivers, and the outlet of Chilkat Lake (fig. 9 and table 3). Miscellaneous measurements were made on several smaller streams within the Chilkat River basin.

A continuous-recording gaging station was established on the Klehini River in October 1981. The discharge pattern of the Klehini River is typical of that for glacier-fed streams in this region of southeast Alaska (fig. 10). Sustained high flows occur during periods of greatest glacier melt, normally June, July, and August. The highest flows during early fall are usually caused by rainfall. Lowest flows usually occur from midwinter to midspring, when ground-water discharge sustains flow in the Klehinf and other rivers.

On the basis of streamflow measurements, discharge of the Tsirku River correlates closely with that of the Klehini River (fig. 11), because their basins have similar physiographic and iydrologic characteristics. Owing to the similarities of the basins, monthly and annual mean flow of the Tsirku River can be estimated from the continuous record on the Klehini River using techniques 

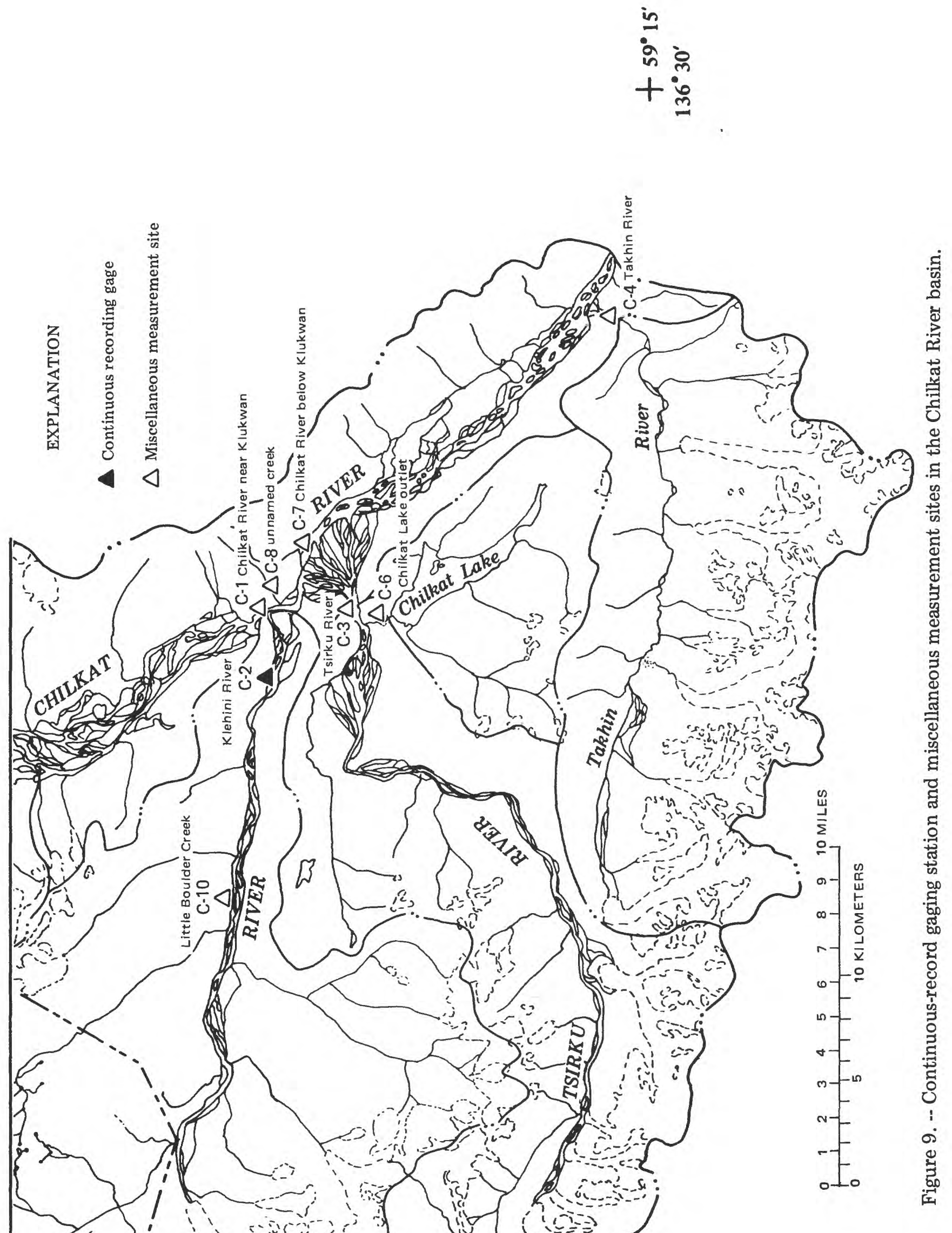

运 
Table 3.--Drainage area, period of record, and maximum and minimum discharge for selected streams measured in the Chilkat River basin

$\left[\mathrm{mi}^{2}\right.$, square mile; $\mathrm{ft}^{3} / \mathrm{s}$, cubic foot per second]

\begin{tabular}{|c|c|c|c|c|c|c|}
\hline $\begin{array}{l}\text { Map No. } \\
\text { (f1g. } 9) \\
\end{array}$ & Station No. & Stream & $\begin{array}{c}\text { Drainage } \\
\text { area } \\
\left(\mathrm{mi}^{2}\right)\end{array}$ & $\begin{array}{l}\text { Period } \\
\text { of record }\end{array}$ & $\frac{\text { Discharge }}{\text { Maximum }}$ & $\frac{\left(\mathrm{ft}^{3} / \mathrm{s}\right)}{\text { Minimum }}$ \\
\hline$C-1$ & 15056500 & $\begin{array}{l}\text { Chilkat River near } \\
\text { Klukwan. }\end{array}$ & 760 & $\begin{array}{r}1959-1961 \\
1981-1982\end{array}$ & $\begin{array}{r}{ }^{3} 20,400 \\
{ }^{3} 7,100\end{array}$ & $\begin{array}{r}80 \\
300\end{array}$ \\
\hline$C-2$ & 15056560 & $\begin{array}{l}\text { Klehini River near } \\
\text { Klukwan. }\end{array}$ & 245 & $\begin{array}{l}{ }^{2} 1981 \\
{ }^{1} 1982-1983\end{array}$ & 9,000 & 116 \\
\hline$c-3$ & 15056580 & $\begin{array}{l}\text { Tsirku River near } \\
\text { K.1ukwan. }\end{array}$ & 230 & ${ }^{2} 1981-1983$ & 5,390 & 142 \\
\hline$C-4$ & 591630135410200 & $\begin{array}{l}\text { Takhin River at } \\
\text { mouth. }\end{array}$ & 100 & ${ }^{2} 1981-1982$ & 722 & - \\
\hline $\mathrm{C}-8$ & 592436135545000 & $\begin{array}{l}\text { Unnamed creek south } \\
\text { of Wells near } \\
\text { Klukwan. }\end{array}$ & ${ }^{4} 2$ & ${ }^{2} 1981-1982$ & 4 & 0 \\
\hline$C-10$ & 592546136074700 & $\begin{array}{l}\text { Little Boulder } \\
\text { Creek. }\end{array}$ & 25 & ${ }^{2} 1981-1982$ & 92 & 21 \\
\hline
\end{tabular}

1 Continuous streamflow record.

2 Miscellaneous measurements only.

3 Mean flow for perlods of record is $3,261 \mathrm{ft}^{3} / \mathrm{s}$.

4 Approximate.

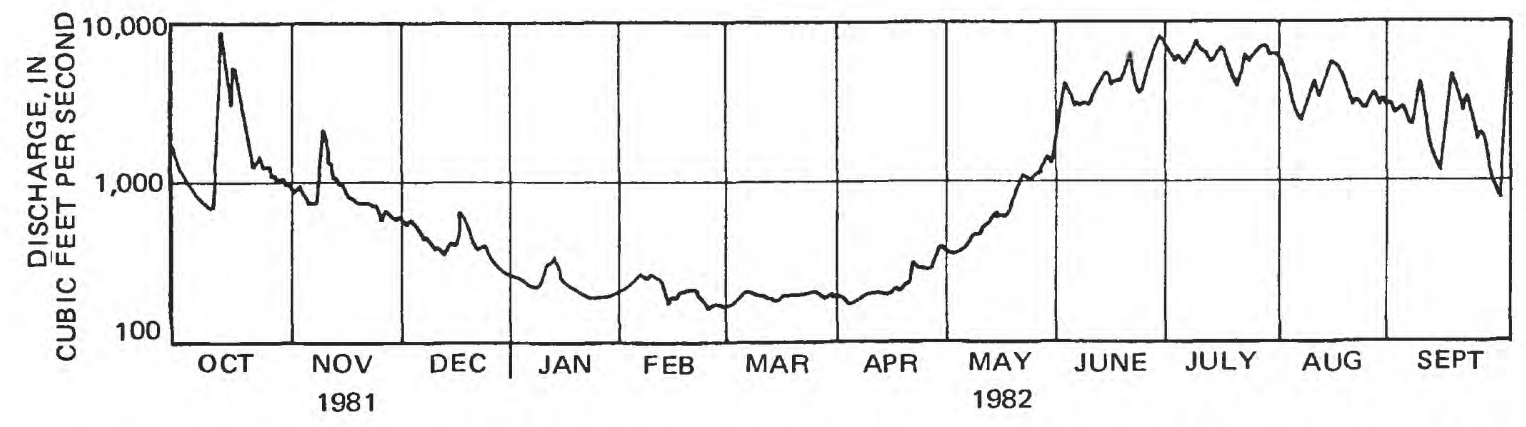

Figure 10.--Hydrograph for Klehini River (15056560), October 1981 to September 1982. 


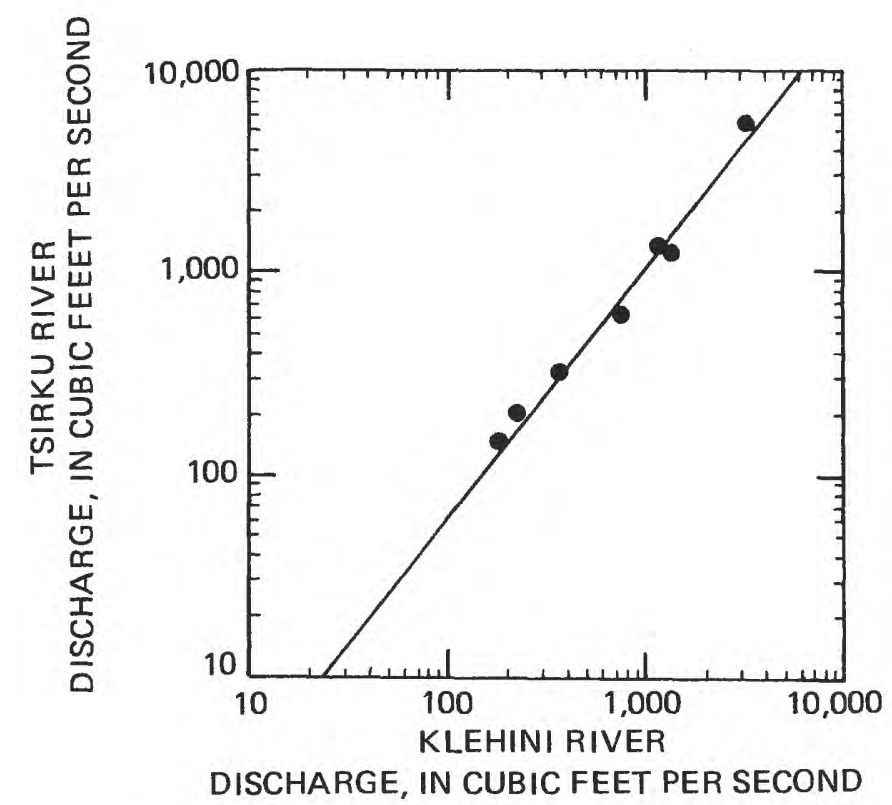

Figure 11.--Discharge relation between Klehini and Tsirku Rivers.

described by Riggs (1969). The Tsirku River also exhibits the same seasonal streamflow fluctuations as the Klehini River (table 4).

A seepage run, a series of stream discharge measurements along a stream reach, was made in the Tsirku alluvial fan area on Apri1 6, 1982, during an early spring low-flow period (fig. 12). Comparison of discharge measurements indicates that, of a total flow of $142 \mathrm{ft}^{3} / \mathrm{s}$ at the head of the $\mathrm{fan}, 74 \mathrm{ft}^{3} / \mathrm{s}$, or 52 percent of that flow, was from the Little Salmon River and $68 \mathrm{ft}^{3} / \mathrm{s}$, or 48 percent, was from Clear Creek. About half the flow of Clear Creek at its mouth was derived from Chilkat Lake.

Table 4.- Monthly mean flow for Klehini and Tsirku Rivers, 1982 water year

(Oct. 1, 1981 - Sept. 30, 1982)

\begin{tabular}{|c|c|c|c|c|c|c|c|c|c|c|c|c|c|}
\hline \multirow[b]{2}{*}{ Stream } & \multicolumn{12}{|c|}{ Monthly mean flow, in cubic feet per second } & \multirow{2}{*}{$\begin{array}{c}\text { Annual } \\
\text { mean }\end{array}$} \\
\hline & Oct. & Nov. & Dec. & Jan. & Feb. & Mar. & Apr. & Nay & June & July & Aug. & Sept. & \\
\hline Klehini River & 2,012 & 905 & 446 & 244 & 217 & 199 & 238 & 789 & 4,266 & 5,424 & 3,293 & 2,329 & 1,706 \\
\hline Tsirku River & 2,500 & 900 & 345 & 185 & 155 & 143 & 177 & 780 & 6,200 & 8,600 & 4,600 & 2,950 & 2,000 \\
\hline
\end{tabular}




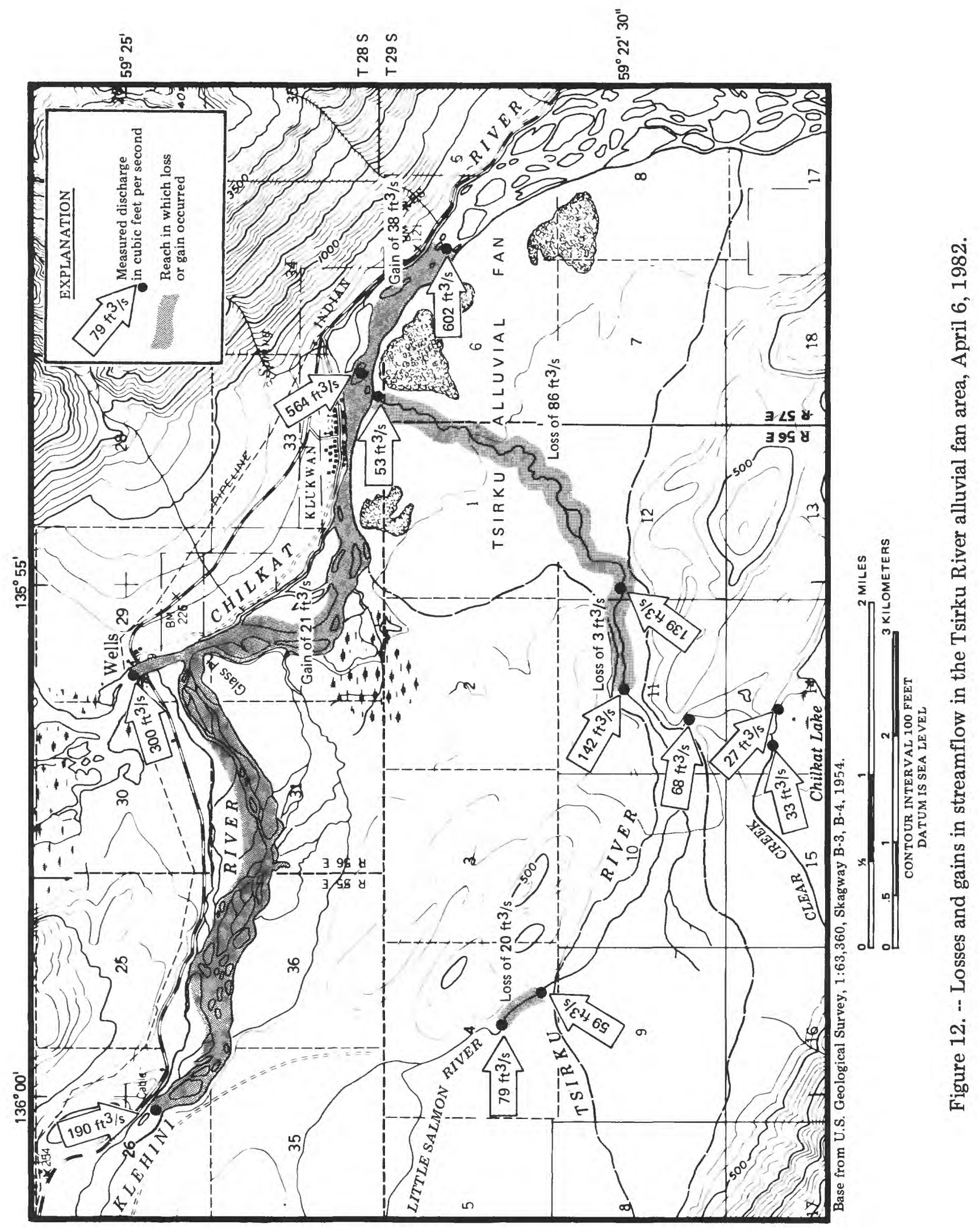




\section{Chemical Muality}

Throughout the basin, surface water is generally a calcium bicarbonate type (f1g. 13 and table 2), except in an unnamed stream (site C-8) on the Klukwan alluvial fan east of the community of Klukwan. This stream had a greater concentration of dissolved sulfate and a greater specific conductance than other sites sampled. Iron concentration may be very high (up to 53,000 $\mu \mathrm{g} / \mathrm{L}$ in the Tsirku River on August 19, 1981), especially during summer high-flow periods on all streams sampled within the basin (table 2). Anomalously high concentrations of barium in the Klehini, Tsirku, and Takhin Rivers and Glacier Creek, probably reflect the presence of barite deposits in these basins (MacKevett and others, 1974). Water temperatures in glacial streams ranged from near freezing in winter to $6{ }^{\circ} \mathrm{C}$ during the summer months. Small nonglacial streams can be expected to be somewhat warmer than glacier-fed streams in summer months.

\section{Suspended Sediment}

Suspended-sediment samples were collected during high- and low-flow periods in August 1981 and April 1982, respectively, on the Chilkat River, the Tsirku River above Tsirku alluvial fan, and the Klehini River. Although there are not enough data to compute statistically valid sediment concentrations on a monthly or yearly basis, some general conclusions can be drawn from the information available.

At low-flow conditions, all three rivers carried relatively low concentrations of suspended sediment $(1-16 \mathrm{mg} / \mathrm{L}$ or $0.38-13 \mathrm{ton} / \mathrm{d})$ in comparison to the concentration at higher flow perlods $(361-1,530 \mathrm{mg} / \mathrm{L}$ or $6,360-22,300 \mathrm{ton} / \mathrm{d})$ (table 2). During the low-flow sampling, the Chilkat River carried almost 20 times more suspended sediment than the Tsirku or Klehini Rivers (fig. 14). This is most likely a function of stream gradients and available materlal, which consists mostly of fine-grained sediment in the Chilkat River near Klukwan but coarse material in the Tsirku and Klehini Rivers. At high flow, the suspended-sediment load increases by three to four orders of magnitude in each stream (fig. 14). At high flows, however, the Tsirku River carries a slightly greater sediment load than the Klehini and Chilkat Rivers. This higher sediment load is probably due in part to a greater abundance of glaciers (and their included debris) in the Tsirku basin.

\section{GROUND WATER}

Ground water in the Chilkat River basin occurs under unconfined and confined conditions in bedrock and alluvium. Unconfined ground water is usually found in alluvium in valleys, but confined conditions may occur in alluvium overlain by clay and silt at depth or at the base of steep alluvial fans on the sides of mountains, and in fractured bedrock beneath valleys.

Bedrock aquifers in the Chilkat basin transmit water through secondary structures such as fractures and joints. Primary porosity (created during formation of the rocks) is probably negligible. Permeability of the rocks may be greater near faults where rock movement has caused more intensive fracturing. However, no data are avallable to quantify bedrock permeability. 


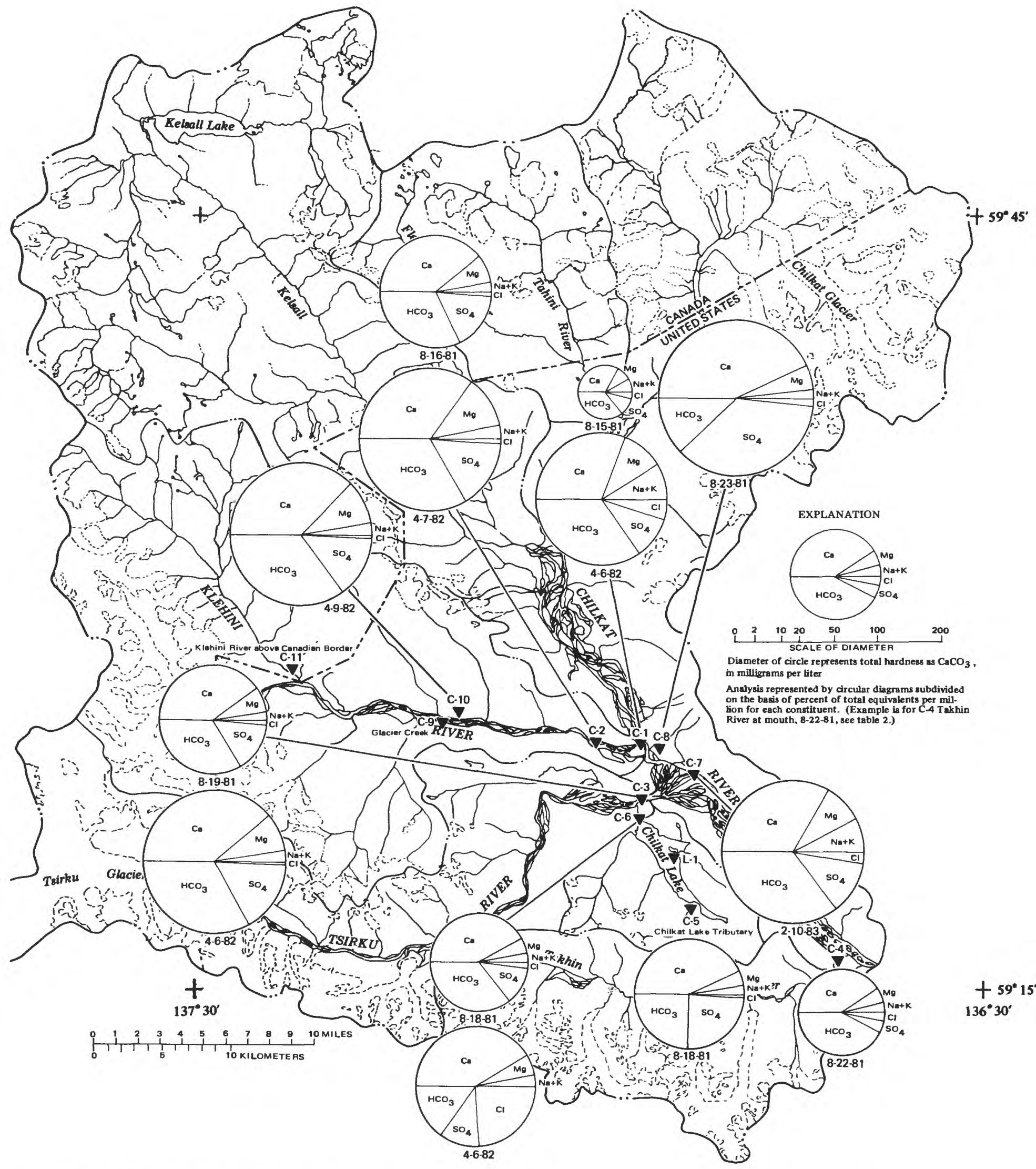

Figure 13. -- Surface-water quality sites in Chilkat River basin, percentage of major cations and anions, and total hardness. 


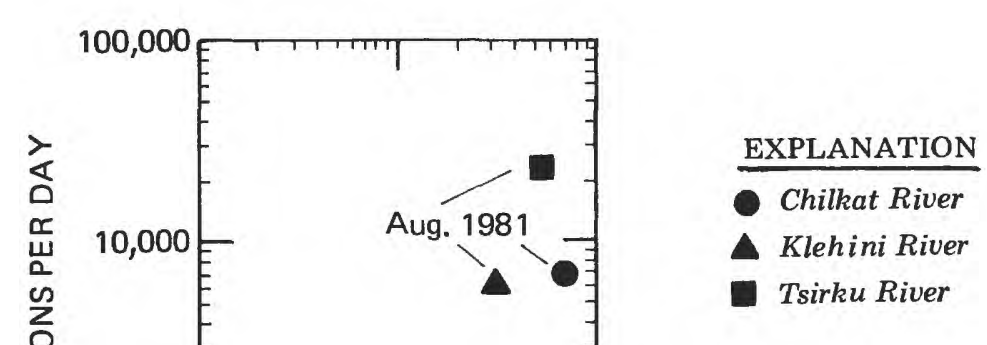

Figure 14.--Suspended-sediment discharge versus stream discharge for Chilkat, Klehini, and Tsirku Rivers at high-and low-flow periods.

Alluvial/colluvial fans along the east side of the Chilkat River valley consist of detritus eroded from the steep flanks of the Takshanuk Mountains. Perennial seeps and springs flowing from these fans into the Chilkat Piver sustain the flow in small tributary channels that, in many cases, salmon favor for spawning. The K1ukwan alluvial fan, a large fan aquifer, supplies water to a spring that is used as a year-round source of water for the village of Klukwan.

Alluvial aquifers that underlie major river valleys are commonly very thick. Data from selsmic traverses across the Chilkat River valley near Klukwan Indicate that depth to bedrock is greater than $850 \mathrm{ft}$ below land surface (f1g. 15). A selsmic traverse in the Klehini Rlver valley at mile 27 Haines Highway, indicates depth to bedrock of at least $250 \mathrm{ft}$. A traverse across the $\mathrm{flat}$ outwash plain between the Klehini and Tsirku River valleys in the area of the Little Salmon River indicates a depth to bedrock of at least $200 \mathrm{ft}$. A11 seismic data were analyzed by the methods of Scott and others (1972).

Interpretation of seismic traverses in the Little Salmon Creek area indicates that unconsolidated gravels are continuous between the Klehini, Tsirku, and Chilkat valleys near the mouth of the Klehini River. Aquifers in these interconnected gravels are probably hydraulically continuous. The water table in those aquifers 

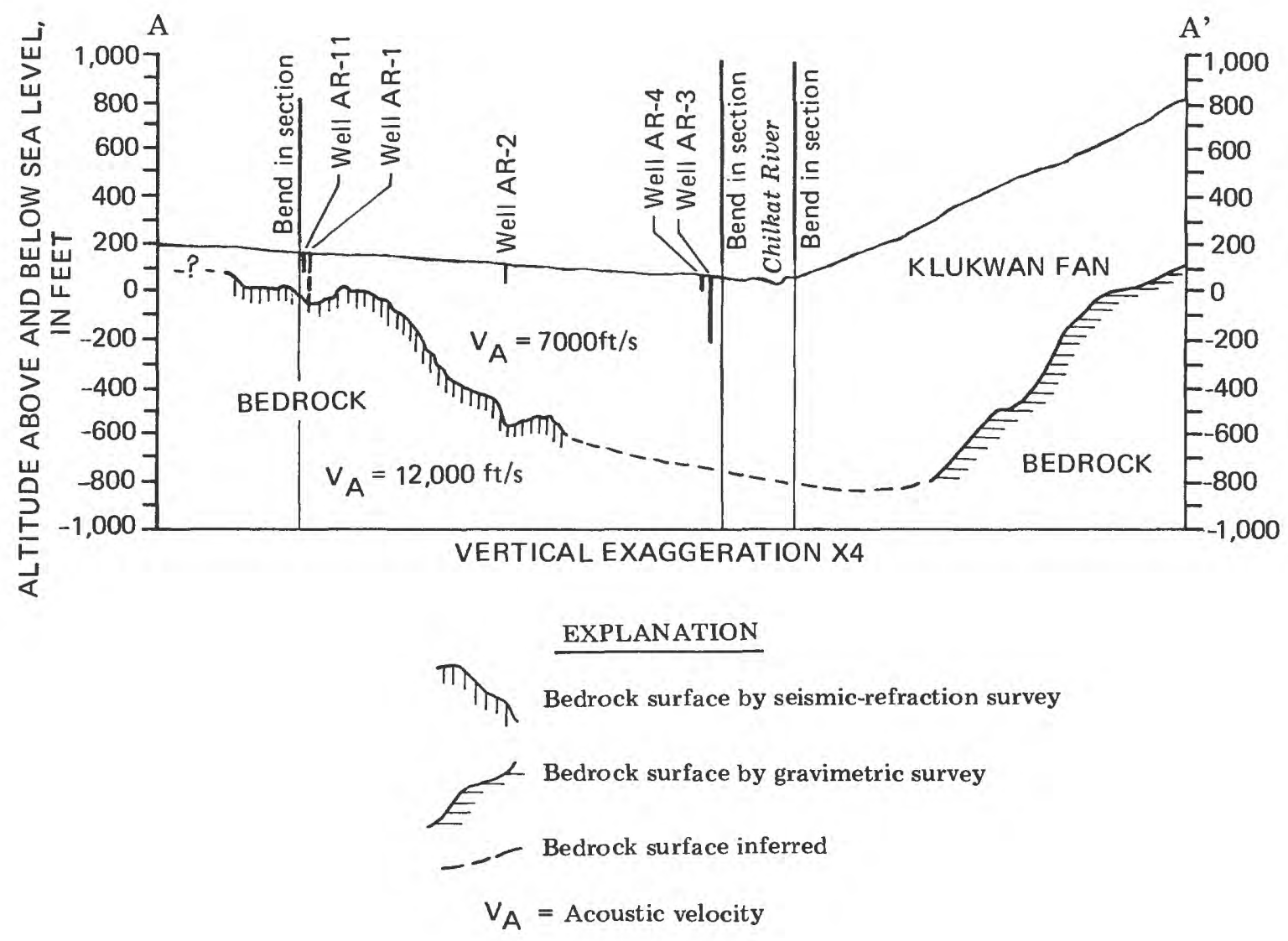

Figure 15. -- Cross section across Chilkat Valley and Tsirku alluvial fan showing bedrock depth from seismic refraction and gravimetric data. See figure 17 for location of line A-A'. (Gravimetric data, 1972, from M.M. Holmes, Klukwan Iron Ore Co., written communication.)

has not been mapped in the Klehinf Vallev nor in much of the Chilkat Valley. However, as in most alluvial-valley aquifers, the water table probably slopes downvalley at approximately the gradient of the valley axis.

Analyses of samples from four of the observation wells indicate that the ground water has a slightly greater dissolved-solids content, but is otherwise chemically similar to the streams. Results of the analyses are on table 5 and shown graphically in figure 16 .

\section{TSIRKU RTVER ALLUVIAL FAN}

The 5-square-mile Tsirku River alluvial fan is a low-gradient alluvial fan deposited by the Tsirku River as it leaves the confines of its bedrock valley and flows into the Chilkat River valley (fig. 17). The Chilkat River borders the toe 
Q AR-10 Observation well and field number (see table 5)

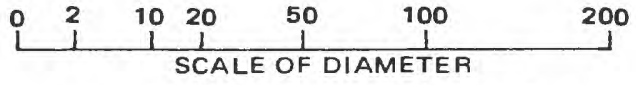

(total hardness, in $\mathrm{mg} / \mathrm{L}$ as $\mathrm{CaCO}_{3}$ )

SEE FIGURE 13 FOR FURTHER EXPLANATION

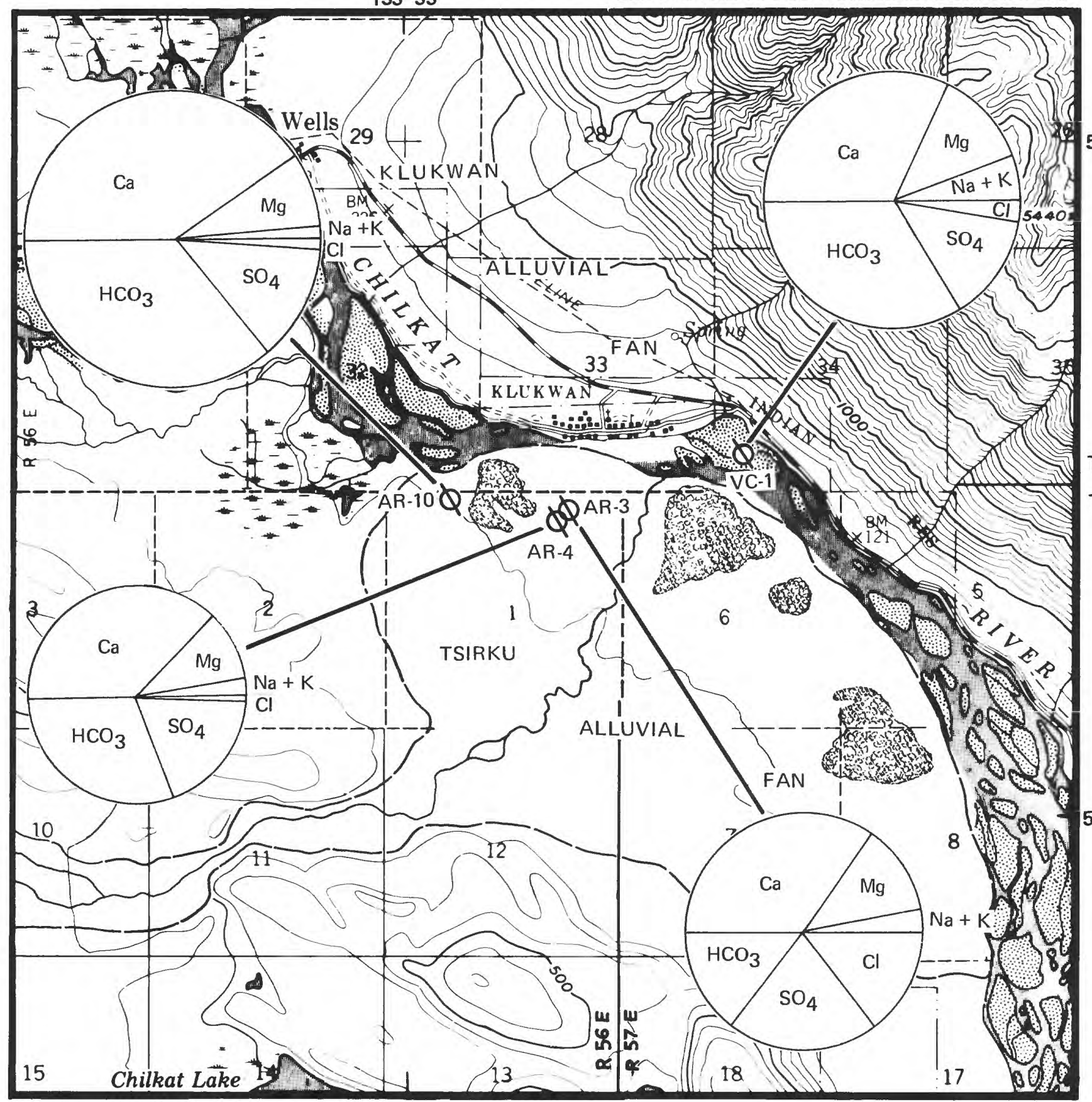

$59^{\circ} 25^{\prime}$

Base from U.S. Geological Survey, 1:63,360, Skagway B-3, B-4, 1954.

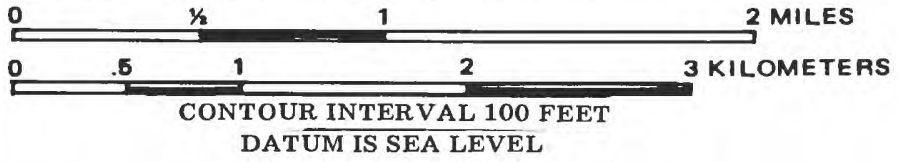

Figure 16. -- Ground-water-quality sites on and near the Tsirku alluvial fan, percentage of major cations and anions, and total hardness. 
Table 5.--Ground-water quality data for four observation wells in the Chilkat River basin [ft, foot; $\mu \mathrm{S} / \mathrm{cm}$ at $25^{\circ} \mathrm{C}$, microsiemens per centimeter at 25 degrees Celsius; ${ }^{\circ} \mathrm{C}$, degree Celsius; NTU, nephelometric turbidity unit; --, no data ]

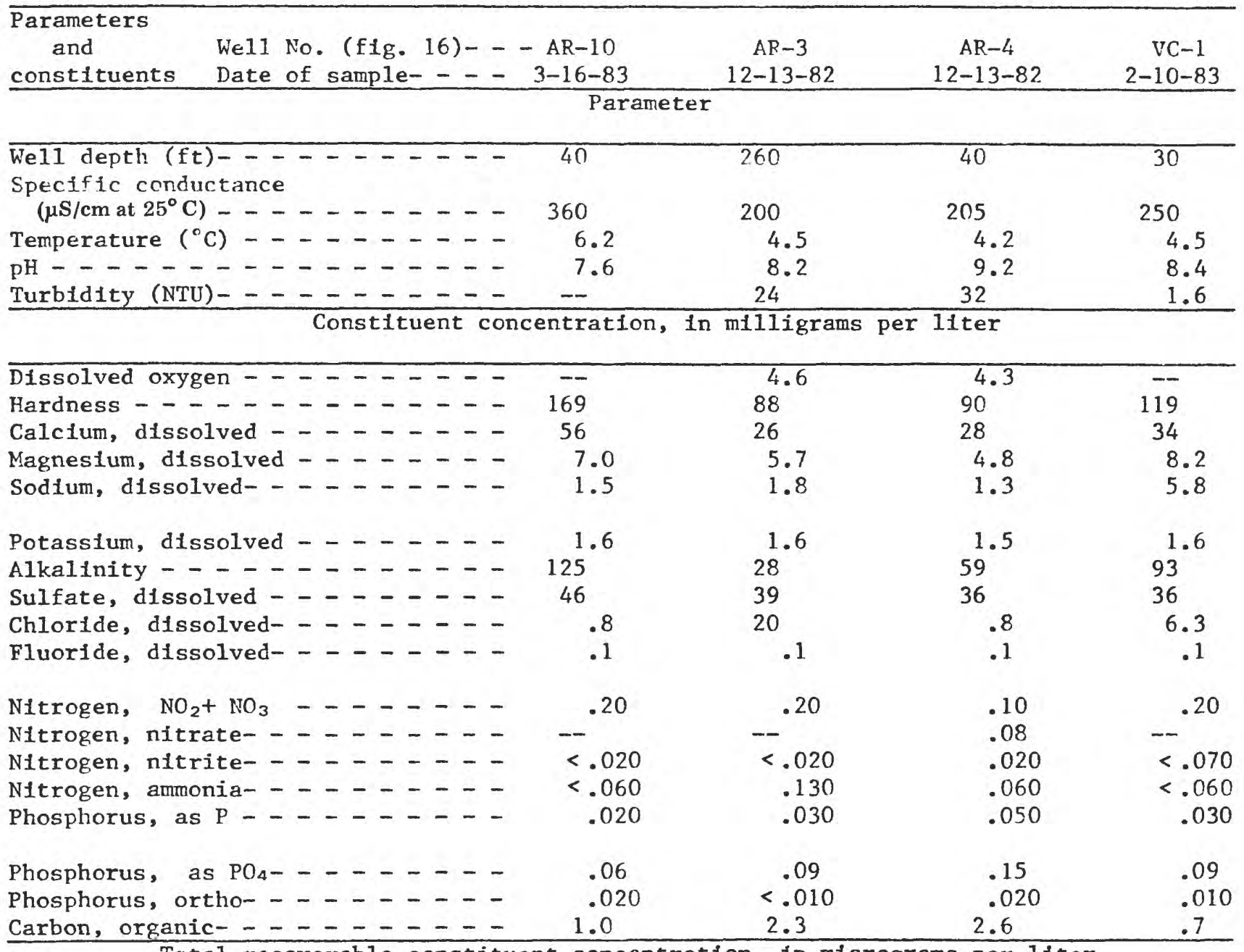

Total recoverable constituent concentration, in micrograms per liter

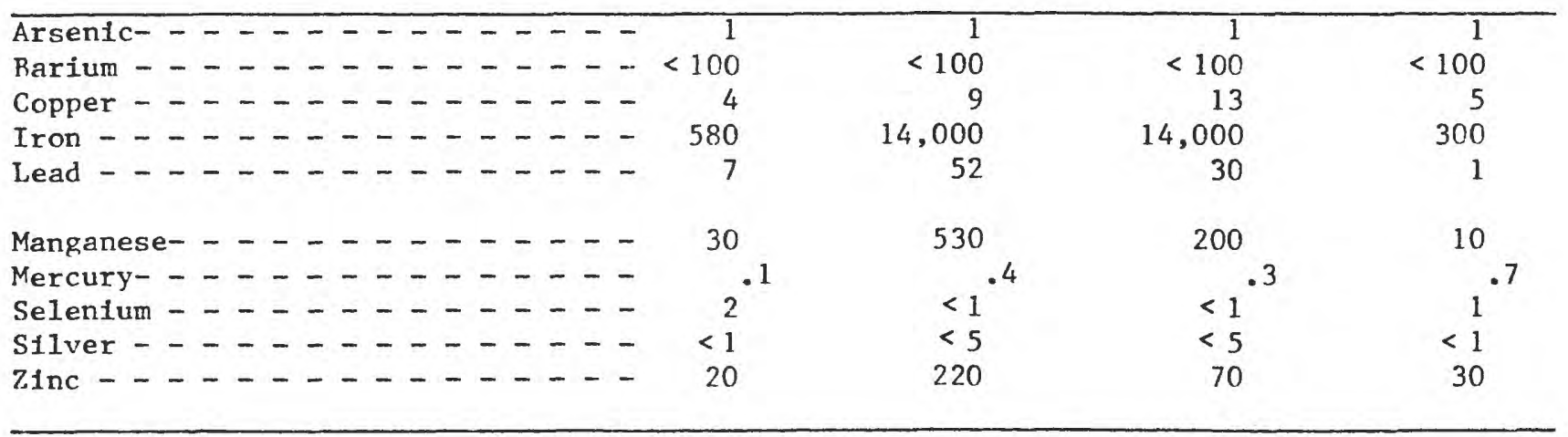




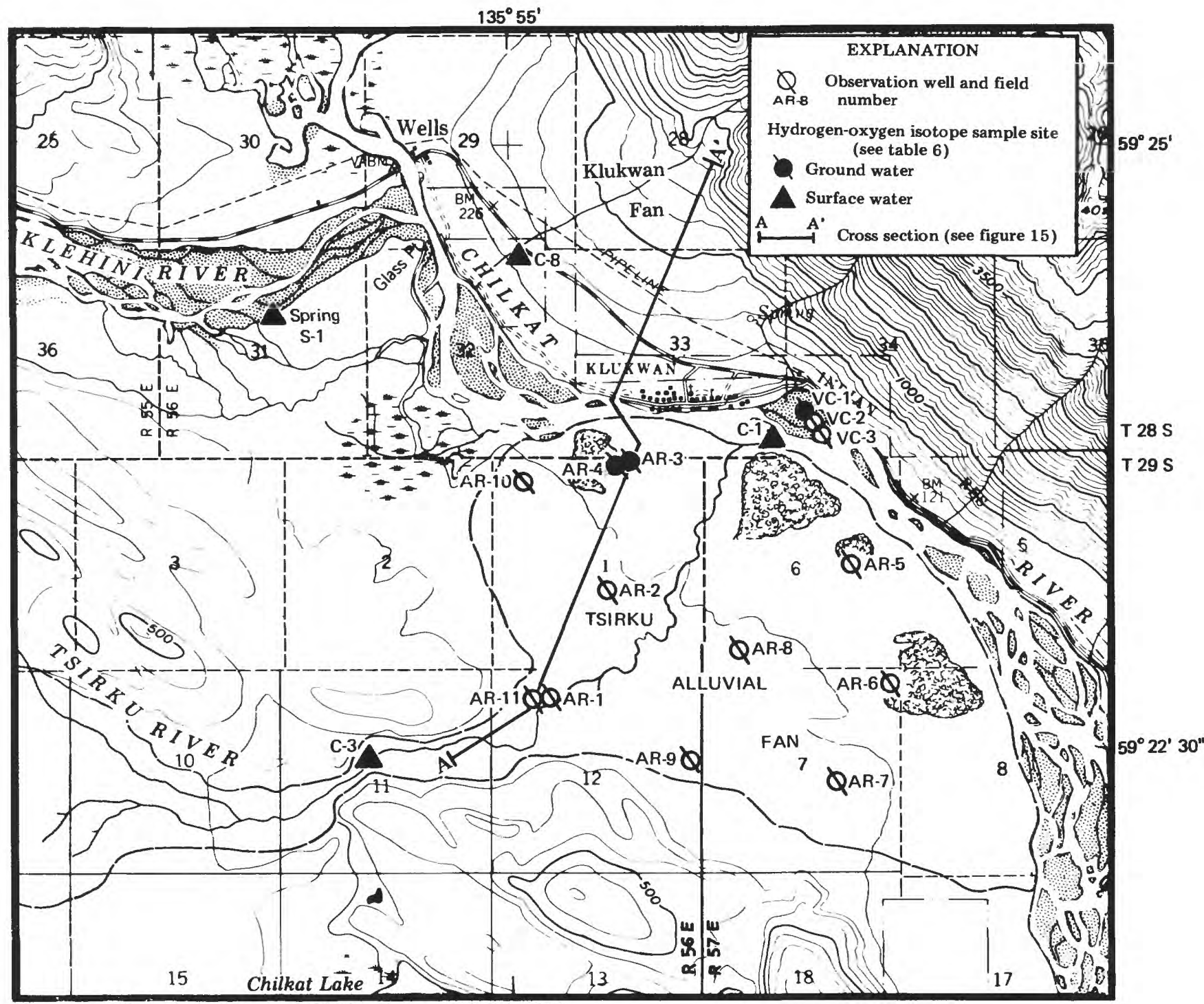

Base from U.S. Geological Survey, 1:63,360, Skagway B-3, B-4, 1954.

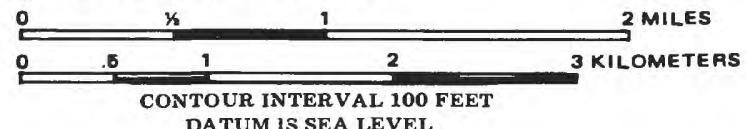

DATUM IS SEA LEVEL

Figure 17. -- Tsirku alluvial fan and vicinity, locations of observation wells (drilled NovemberJanuary 1982-83), and hydrogen-oxygen isotope sampling sites.

of the fan along the toe's entire 4.9-mile perimeter. During low-flow periods in 1982 and 1983, the main channel on the fan was about $2 \mathrm{mi}$ long. The surface of the fan descends from an altitude of about $160 \mathrm{ft}$ near the head to about $95 \mathrm{ft}$ near the toe. This vertical drop of $65 \mathrm{ft}$ in a distance of about $1.8 \mathrm{mi}$ is equivalent to a gradient of $36 \mathrm{ft} / \mathrm{mi}$, in contrast to a gradient of $48 \mathrm{ft} / \mathrm{mi}$ for the Tsirku River directly above the fan.

The fan is composed of material that ranges in size from boulders greater than $1 \mathrm{ft}$ in diameter to silt- and clay-sized particles (fig. 18). Most of the perimeter of the fan is covered by low-lying bushes and grasses growing on inactive channels and on overbank deposits. Stands of cottonwood trees grow along the toe and on the sides of the fan. However, most of the upper and middle parts of the fan are unvegetated or very sparsely vegetated. 


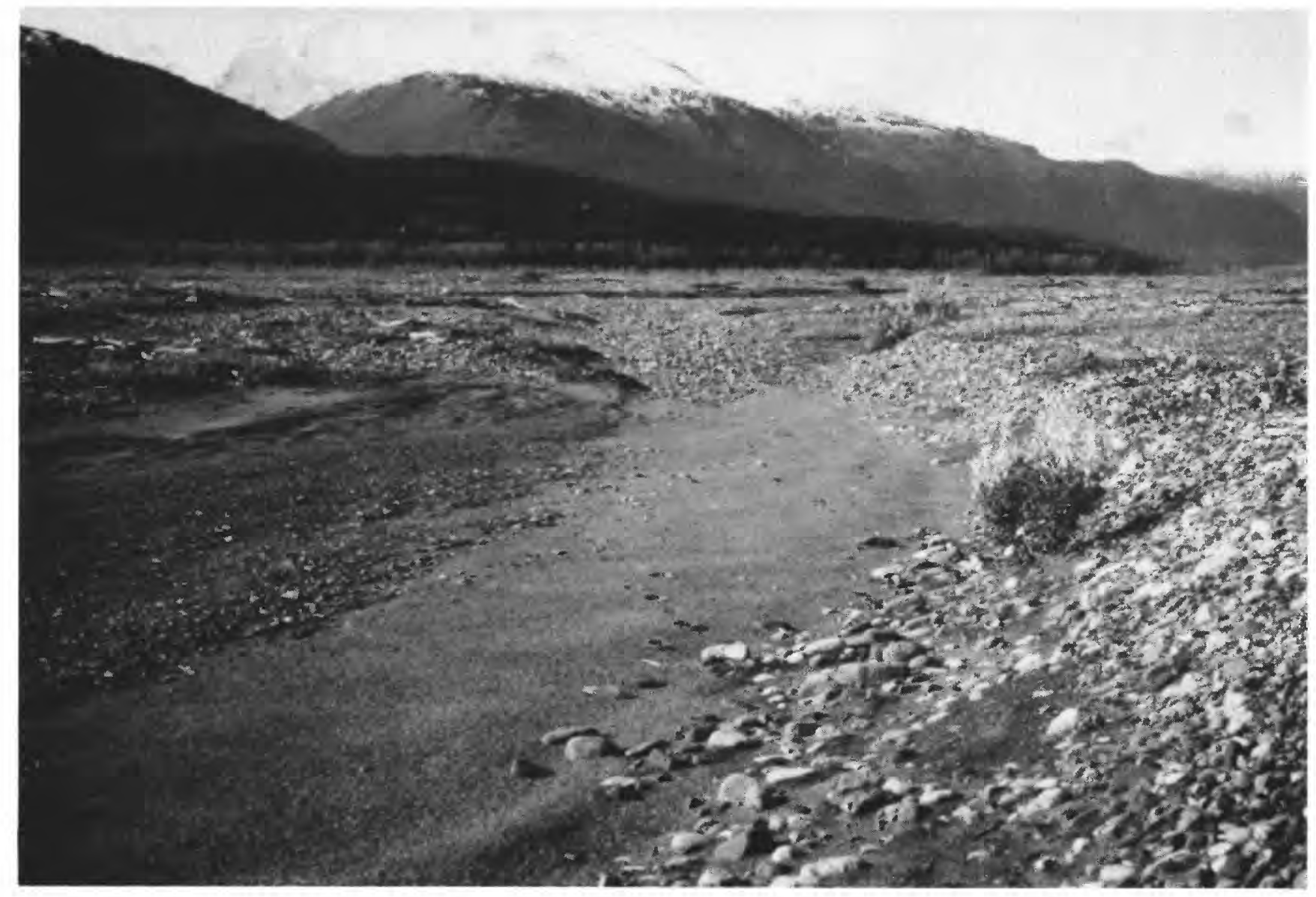

Figure 18. -- Tsirku alluvial fan, October 5, 1981. View is northwest toward head of fan (low dark hills in upper part of photograph). Note variance in size of sediment on fan surface. Also note inactive channel in the middle of photograph with finer sediment and typical vegetation growing on fan surface (vegetation is approximately 2.5 feet high).

\section{Glacial History}

The Tsirku alluvial fan area presumably underwent multiple glacial episodes as did most of this part of southeast Alaska. The Chilkat River valley and the area of the fan appear to have been ice free earlier than the surrounding areas such as Glacier Bay National Monument (H. J. Kaiser Co., written commun., 1972). During the last major glacial period (about 10,000 years ago), sea level was considerably lower than at present, perhaps by as much as $300 \mathrm{ft}$.

As glaciers in the Chilkat River valley retreated, large amounts of sediment were deposited as outwash, valley train, and deltaic deposits. An average rate of deposition would have been about $0.1 \mathrm{ft} / \mathrm{yr}$ assuming the area became ice free 10,000 years ago and the glacier had scoured to bedrock. This compares with an accretion rate for Klukwan alluvial fan of $0.4 \mathrm{ft} / \mathrm{yr}$ calculated from a carbon-14 dated piece of wood (H. J. Kaiser Co., written commun., 1972). The types of sediment filling the valley vary from till (ice-contact materials) to alluvium (outwash materials) to deltaic and marine deposits. The alluvial deposits are better sorted (lesser percentage of silt and clay) than the till. 
The relation of the altitude of the bedrock valley floor in the Tsirku alluvial fan area, at an estimated $850 \mathrm{ft}$ below sea level ( $\mathrm{fig} .15$ ), to present-day sea level indicates that sea water could have intruded into the valley. Test drilling at the mouth of the Chilkat River, $20 \mathrm{mi}$ downstream, penetrated a marine deposit more than $100 \mathrm{ft}$ thick whose upper surface is $20 \mathrm{ft}$ below present sea level (Alaska Dept. of Highways, 1968). However, no marine deposits were identified in observation well AR-3, which was drilled to a depth of $260 \mathrm{ft}$ below land surface, about $146 \mathrm{ft}$ below present sea level. If the sea once did extend up the Chilkat Valley as far as the Tsirku alluvial fan area, marine deposits may be present at a depth greater than $260 \mathrm{ft}$.

\section{Fan Sedimentology and Morphology}

The composition of sediment and the channel morphology of the Tsirku alluvial fan reflect its depositional history. An alluvial fan is built by both lateral and vertical migration of channels. As sediment is deposited, the channel eventually becomes clogged, resulting in a diversion of water from that channel toward an area that is lower (Fahnestock, 1967). A new channel is then formed, in which the process begins again in the area of the new channel.

The vertical sedimentary structure of the fan is also the result of a repetitive bullding process. Coarse sediment is selectively deposited by different quantities and velocities of water in the channel. A decrease in velocity results in a decrease in the size of sediment that can be transported until, with a decrease in flow of water, the velocity slows sufficiently so that only silt- and clay-sized material can be transported. Eventually even these fine-grained materials are deposited upon the coarser sediments as flow ceases.

\section{TSIRKU ALLUVIAL FAN AQUIFER}

The alluvium of the Tsirku alluvial fan comprises an unconfined aquifer bounded on the northeast and southwest by the bedrock walls of the valley. At the northwest and southeast boundaries the aquifer grades into and is hydraulically continuous with alluvial aquifers of the Klehini and Chilkat Valleys. The base of the aquifer in the eastern part of the Chilkat Valley has not been defined, but is likely to be the contact between alluvial material and low-permeabllity marine or deltaic deposits at a depth greater than $260 \mathrm{ft}$ below land surface. On the north, the Tsirku alluvial fan sediments interfinger with sediments of the Klukwan alluvial fan (H.J. Kaiser, written commun., 1972). Klukwan alluvial fan sediments are poorly sorted debris-flow deposits of lower permeability than Tsirku alluvial fan sediments.

In the Tsirku alluvial fan aquifer, seasonal fluctuations of the water table are observed in both deep and shallow wells (figs. 19 and 20). In observation well AR-3 (depth, $260 \mathrm{ft}$ ), water levels decreased slowly from December 1982 unti1 about mid-April 1983, then rose rapidly at an average of $0.2 \mathrm{ft} / \mathrm{d}$ until mid-May 1983. Observation well AR-1 (depth, $220 \mathrm{ft}$ ), which is drilled $20 \mathrm{ft}$ into bedrock, shows a similar response, but with a more rapid rise in water level, about $0.6 \mathrm{ft} / \mathrm{d} \mathrm{from}$ mid-April to mid-May. Shallow wells AR-4 and AR-7 (both $40 \mathrm{ft}$ deep) react similarly. Synchronous fluctuations of water levels in both deep and shallow wells indicate hydraulic continuity between deep and shallow parts of the aquifer. 


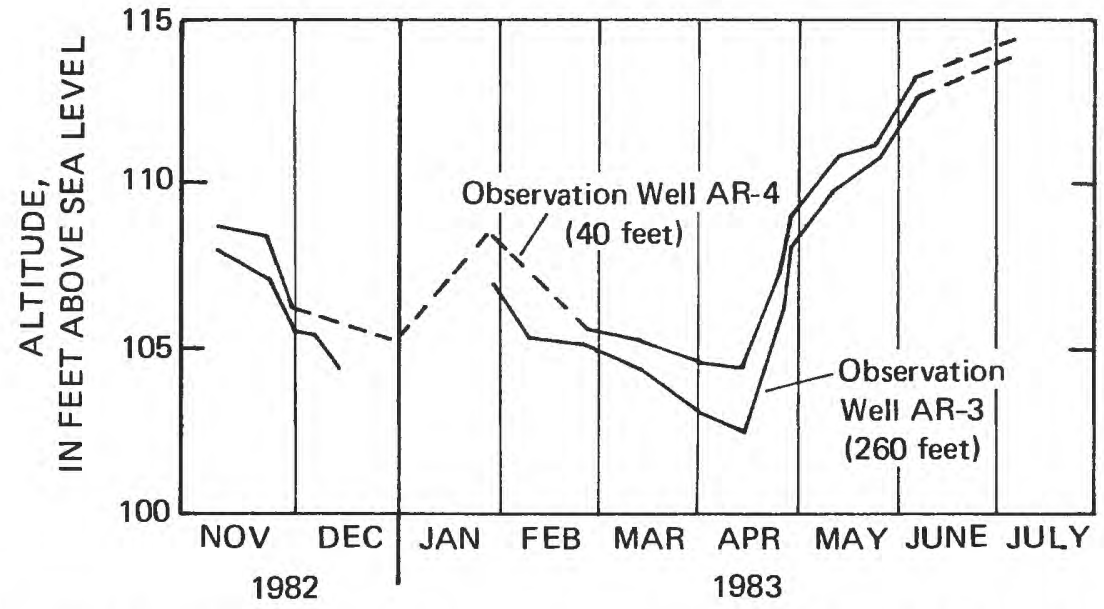

Figure 19. -- Hydrograph of observation wells AR-3 and AR-4 at the toe of the Tsirku alluvial fan showing relation between potentiometric surface in deep and shallow ground-water systems.

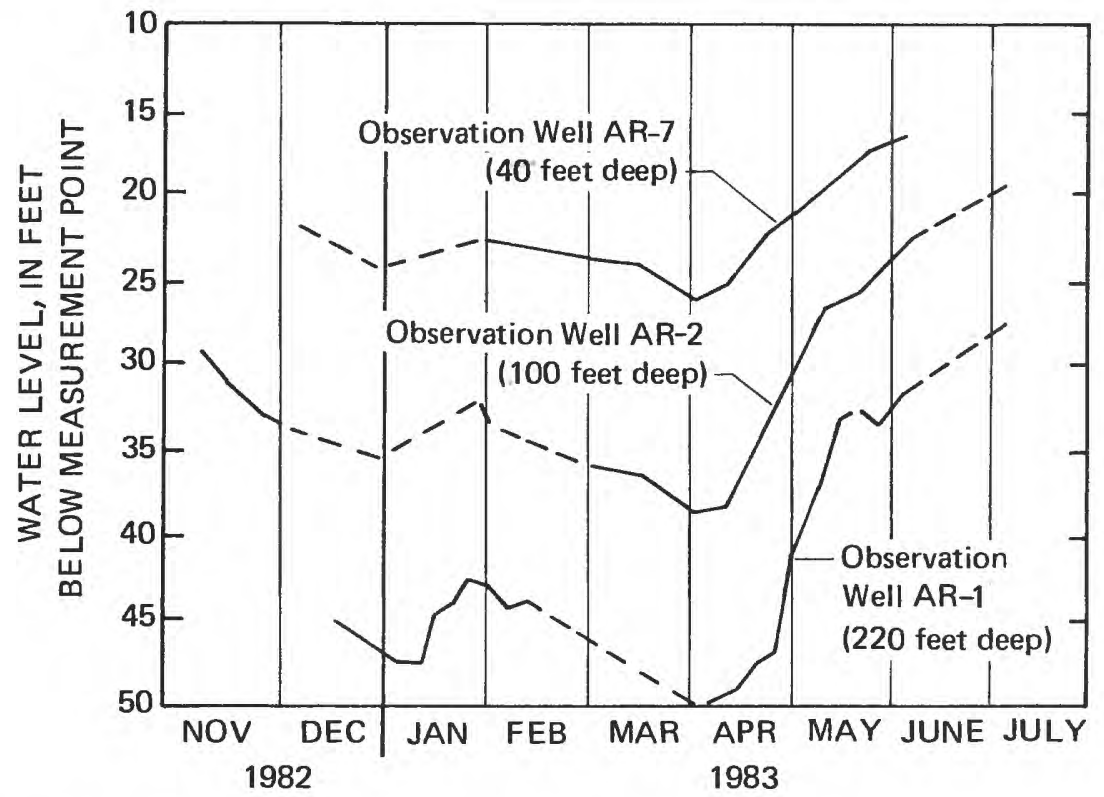

Figure 20. -- Hydrographs of observation wells on the Tsirku alluvial fan.

Flow lines drawn perpendicular to potentiometric-surface contours (fig. 2la and $b)$ indicate that as shallow ground water moves through the head of the fan it spreads out in a deltaic pattern. After the water has moved about one-third of the distance from head to toe of the fan, its direction becomes skewed downvalley. This downvalley trend is most pronounced in late winter (March) data, when the potentlometric surface is lowest. 


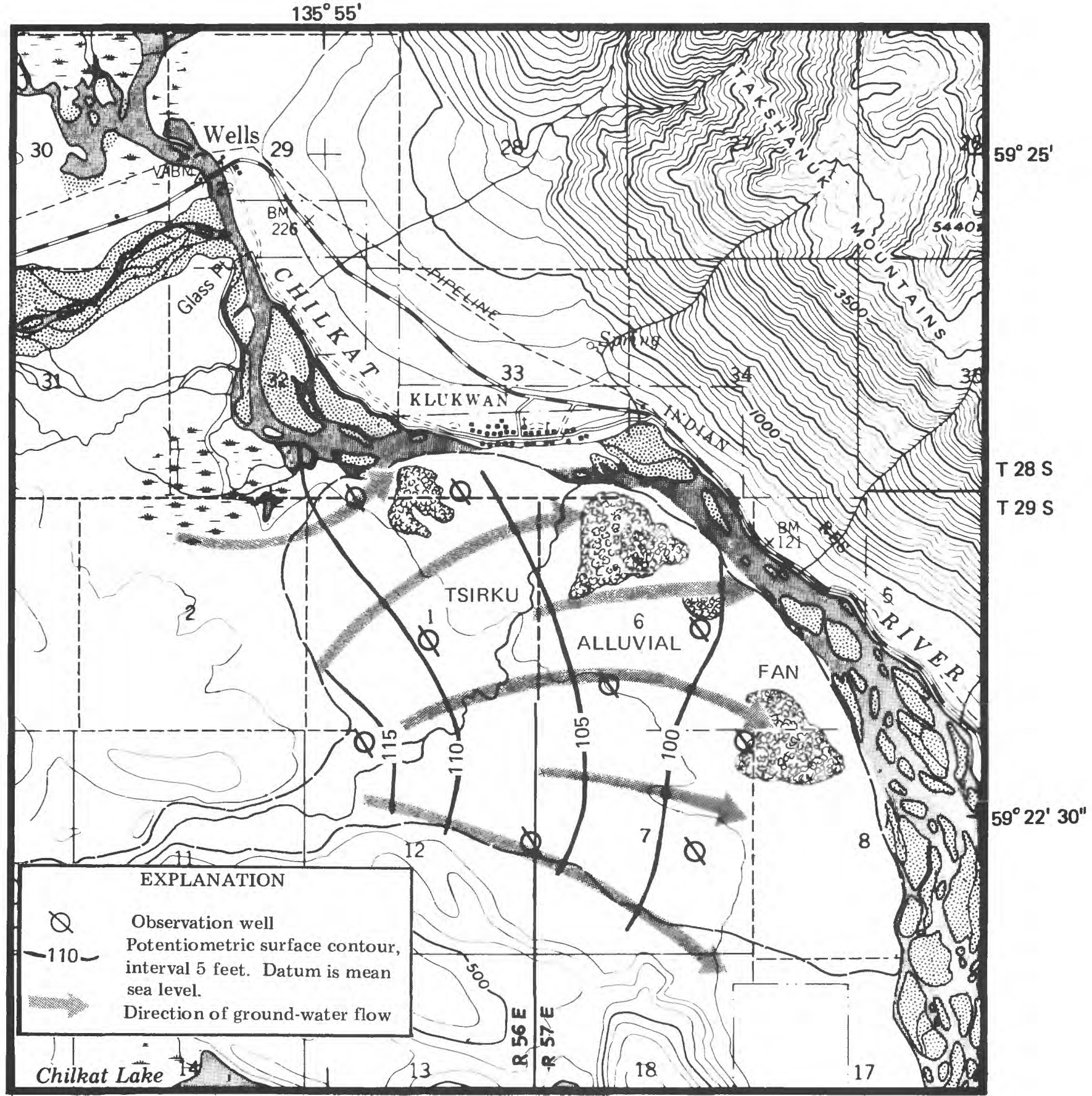

Base from U.S. Geological Survey, 1:63,360, Skagway B-3, B-4, 1954.

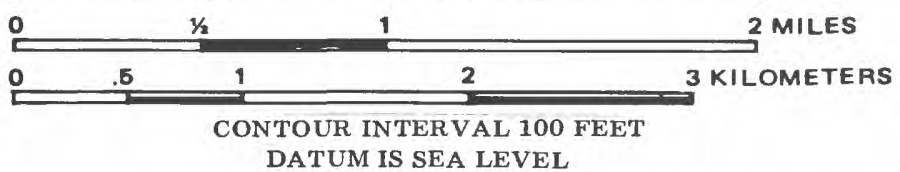

Figure 21a. -- Potentiometric surface map of shallow ground-water system and direction of groundwater movement, Tsirku alluvial fan, March 11-16, 1983. 


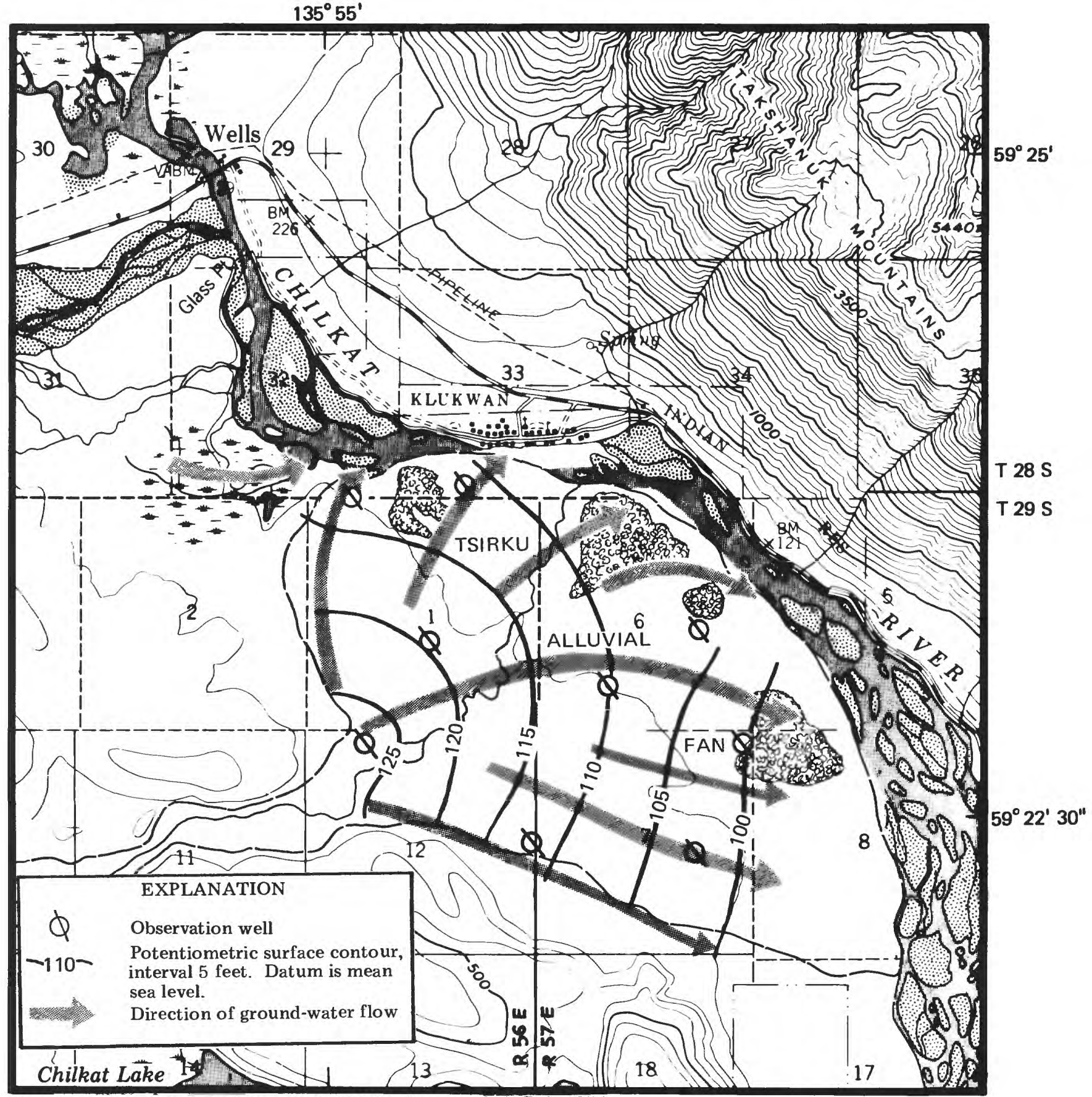

Base from U.S. Geological Survey, 1:63,360, Skagwa y B-3, B-4, 1954.

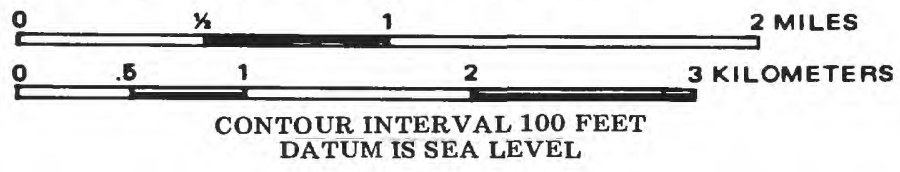

Figure 21b. -- Potentiometric surface map of shallow ground-water system and direction of groundwater movement, Tsirku alluvial fan, May 11, 1983. 
Rates of ground-water flow can be calculated using the equation:

$$
V=\frac{K}{\theta} i
$$

where $V$ is average linear velocity, in feet per day;

$K$ is hydraulic conductivity, in feet per day;

$i$ is hydraulic gradient, a dimensionless variable; and

$\theta$ is porosity of aquifer, expressed as a decimal.

The hydraulic conductivity and porosity have not been determined for the Tsirku alluvial fan sediments. However, hydraulic conductivity of coarse sandy gravel is typically in the range of 200 to $2,000 \mathrm{ft} / \mathrm{d}$. The porosity is estimated to be about 0.25, and the gradient is 0.0052. Ground water accordingly is calculated to move at rates from 4 to $40 \mathrm{ft} / \mathrm{d}$ and travel time of the water from the apex to toe of the fan ranges from approximately 0.5 to 5 years.

Stable isotopes of oxygen and hydrogen can indicate the source of precipitation that recharged the aquifer (Muir and Coplen, 1981). Precipitation at higher altitudes in inland areas is more depleted in oxygen-18 and hydrogen-2 than precipitation near the coast. Oxygen and hydrogen isotopes can also be used as tracers of ground-water movements.

The oxygen 0-18/16 and hydrogen $\mathrm{H}-2 / 1$ isotopic "signatures" of water samples from the Chilkat and Tsirku Rivers near the Tsirku alluvial fan and from shallow observation wells (AR-4, VC-1) near the Chilkat River (table 6) indicate a relatively recent water, probably from a low-altitude, near-coast source (Tvan Barnes, U.S. Geological Survey, oral commun., 1983). However, isotopic data from observation well AR-3 (260 ft) indicate a relatively older water, probably from a higher altitude, continental source (Tyler Coplen, U.S. Geological Survey, oral commun., 1983). Water from the deeper well perhaps originates in recharge areas at the headwaters of the Chilkat basin (in interior British Columbia).

Table 6.--Oxygen and hydrogen isotope data from samples collected at selected surface-water sites and observation wells

\begin{tabular}{lcccc}
$\begin{array}{l}\text { Map No. } \\
\text { (fig. 17) }\end{array}$ & Date & Well depth & Hydrogen $^{2} /$ hydrogen $^{1}$ & Oxygen $^{18} /$ oxygen $^{16}$ \\
(feet) & (per mil) & (per mil) \\
\hline
\end{tabular}

Surface-water site

$\begin{array}{lllll}\text { C-1 } & 02-10-83 & - & -136.0 & -18.1 \\ \text { C-3 } & 12-15-82 & -- & -133.0 & -17.4 \\ \text { C-8 } & 04-08-83 & -- & -142.0 & -18.9 \\ \text { S-1 } & 04-08-83 & -- & -133.0 & -17.8\end{array}$

Observation well

\begin{tabular}{lrrrr} 
AR-3 & $12-13-82$ & 260 & -80.0 & -10.4 \\
AR-4 & $12-13-82$ & 40 & -130.0 & -17.2 \\
VC-1 & $02-10-83$ & 30 & -131.0 & -17.6 \\
\hline
\end{tabular}




\section{Ground-Water Discharge and Recharge}

Ground-water discharge areas on gravel bars in the Chilkat River along the toe of the Tsirku alluvial fan can be easily identifled by ice-free channels during the winter period (fig. 22). The relatively warm $\left(4\right.$ to $6{ }^{\circ} \mathrm{C}$ ) water keeps the channels open in the discharge areas and in a 10-mile reach below the fan. During winter, water levels in observation we11s VC-1, -2 , and -3 (drilled to depths of 30, 15, and $25 \mathrm{ft}$, respectively) in the gravel bars were higher than in the adiacent stream and ground-water flow into the channel was evident. During summer high flow in the Chilkat River, these gravel bars are completely inundated and the ground-water discharge zones are concealed.

Ground-water discharge in the Chilkat River at the toe of the Tsirku alluvial fan is probably caused by a downstream decrease in hydraulic conductivity and thickness of fluvial sediments, and a narrowing of the Chilkat River valley. A downvalley decrease in thickness and hydraulic conductivity of the sediments would

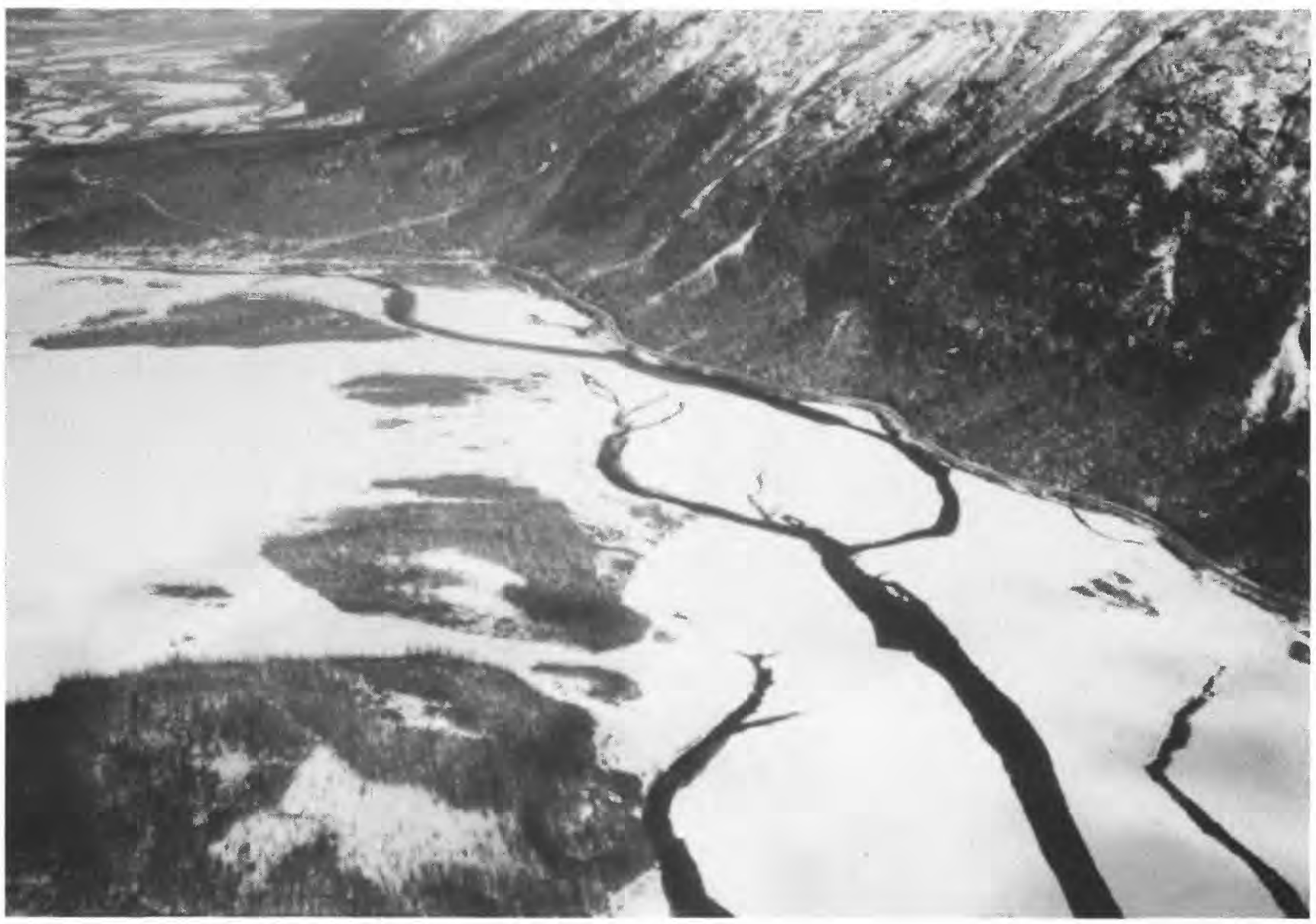

Figure 22. -- Part of toe of Tsirku alluvial fan, and Chilkat River on March 23, 1982. View northwest up Chilkat River valley,Takshanuk Mountains at right of photograph. Note dendritic pattern of open channels in Chilkat River where ground-water discharge at the surface keeps channels open. Klukwan is at upper left corner of photograph. 
Induce a damming effect, cause the potentiometric surface at the toe of the Tsirku alluvial fan to rise above the altitude of the land surface, and result in groundwater discharge. No geochemical, isotopic, or physical evidence was found to indicate that the Chilkat River fault has anv influence on ground-water flow paths or discharge at the toe of the Tsirku alluvial fan.

Other areas of ground-water discharge are present in the channels of the Chilkat River both upstream and downstream from the toe of the Tsirku alluvial fan, and at several locations in the Takhin, Klehini, and Kelsall River valleys. Most of the discharge zones up- and downvalley from the Tsirku alluvial fan are seeps and springs at the bases of the alluvial and colluvial fans on the western slopes of the Takshanuk Mountains (fig. 2). Th1s relatively warm ground water keeps the adjacent and near-downstream reaches of the Chilkat River open (ice free) during winter.

Ground water in the Tsirku alluvial fan is recharged by infiltration of streamflow from the Tsirku River, infiltration of precipitation, and ground-water inflow.

\section{Tsirku Fan Flow System}

The ground-water and surface-water flow systems of the Tsirku fan are interconnected to such a degree that development of a quantitative hydrologic budget (water in - water out) is not possible. However, data are available with which to make estimates of the relative importance of various hydrologic parameters.

The most important source of ground-water recharge to the Tsirku fan aquifer is the Tsirku River ( $\mathrm{fig} .23$ ) and its distributary channels. From late May to early September, up to one-third of the fan's surface area is covered by numerous distributary channels ( $\mathrm{fig} .24$ ). A seepage run conducted on April 6, 1982 ( $\mathrm{flg}$. 12) Indicated that 63 percent $\left(89 \mathrm{ft}^{3} / \mathrm{s}\right)$ of streamflow entering the head of the fan was lost to the fan aquifer. It was not feasible to conduct seepage runs of the fan's "summer" distributary channels. However, the April seepage run, made when the flow was confined in one channel, indicates the importance of streamflow infiltration as a recharge source.

Other sources of recharge to the Tsirku fan include precipitation and groundwater inflow. Precipitation on the 5-square-mile fan is about $21 \mathrm{in} / \mathrm{yr}$ or about 8 $\mathrm{ft}^{3} / \mathrm{s}$. Ground-water inflow through bedrock at the head of the $\mathrm{fan}$ is assumed to be negligible. Ground-water inflow through the Tsirku River alluvium at the head of the fan was calculated to be approximately $0.2 \mathrm{ft}^{3} / \mathrm{s}$ during winter low water-table conditions, and $3.6 \mathrm{ft}^{3} / \mathrm{s}$ during summer high water-table conditions.

The ground-water inflow was calculated using Darcy's law:

$$
Q=K A i
$$

where $Q$ is quantity of ground-water flow, in cubic feet per day;

$K$ is hydraulic conductivity, in feet per day (estimated to be $1,000 \mathrm{ft} / \mathrm{d}$ );

$A$ is cross-sectional area of saturated zone, in square feet (winter 10,000 $\mathrm{ft}^{2}$, summer $60,000 \mathrm{ft}^{2}$ ); and

$i$ is hydraulic gradient (winter 0.0016 , summer 0.0052 ). 


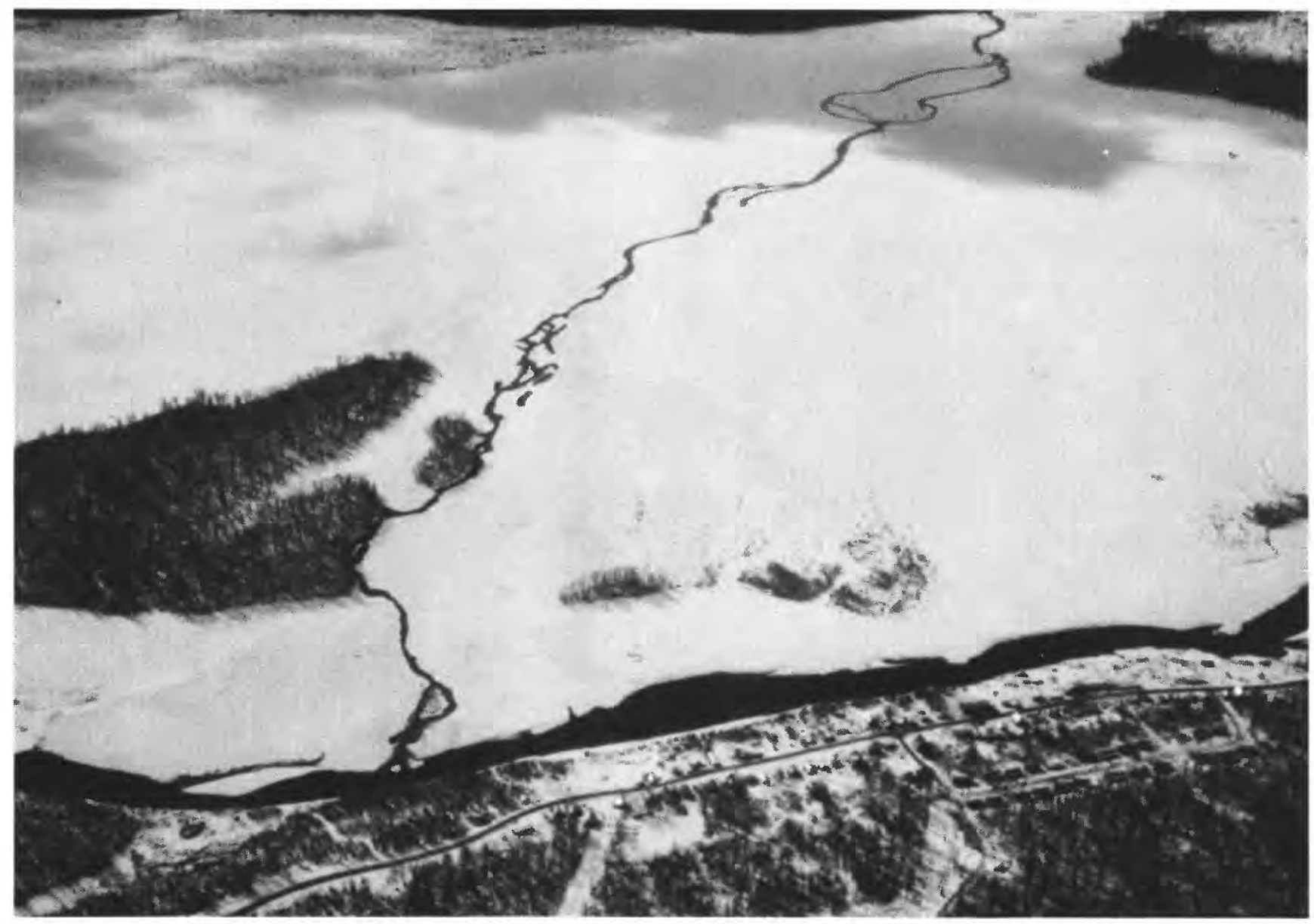

Figure 23. -- Tsirku alluvial fan, March 22, 1982. View southwest toward head of fan, shows single open channel extending across fan and the open channel of Chilkat River along toe of fan. Village of Klukwan is at lower right.

In summary, even if all precipitation on the fan infiltrated, it would only contribute $8 \mathrm{ft}^{3} / \mathrm{s}$. Peak ground-water inflow at the head of the fan is on $1 \mathrm{y}$ about $4 \mathrm{ft}^{3} / \mathrm{s}$. However, streamflow infiltration, even measured at low flow, was 89 $\mathrm{ft}^{3} / \mathrm{s}$. Fiements of the surface-water and ground-water flow systems are shown on figure 25 .

\section{HEAT-FLOW CALCULATIONS}

Heat contained in the relatively warm (average $5{ }^{\circ} \mathrm{C}$ ) ground water that discharges at the toe of the alluvial fan maintains open-water leads in the winter ice cover of the Chilkat River adjacent to and downstream from the fan. If there is no significant change in the ice cover for a period of several days, then heat-flow calculations (Jobson and Keefer, 1979 and Jobson, 1980) can be simplified and used to calculate the amount of ground water that must flow into the river to maintain an observed amount of open water. 


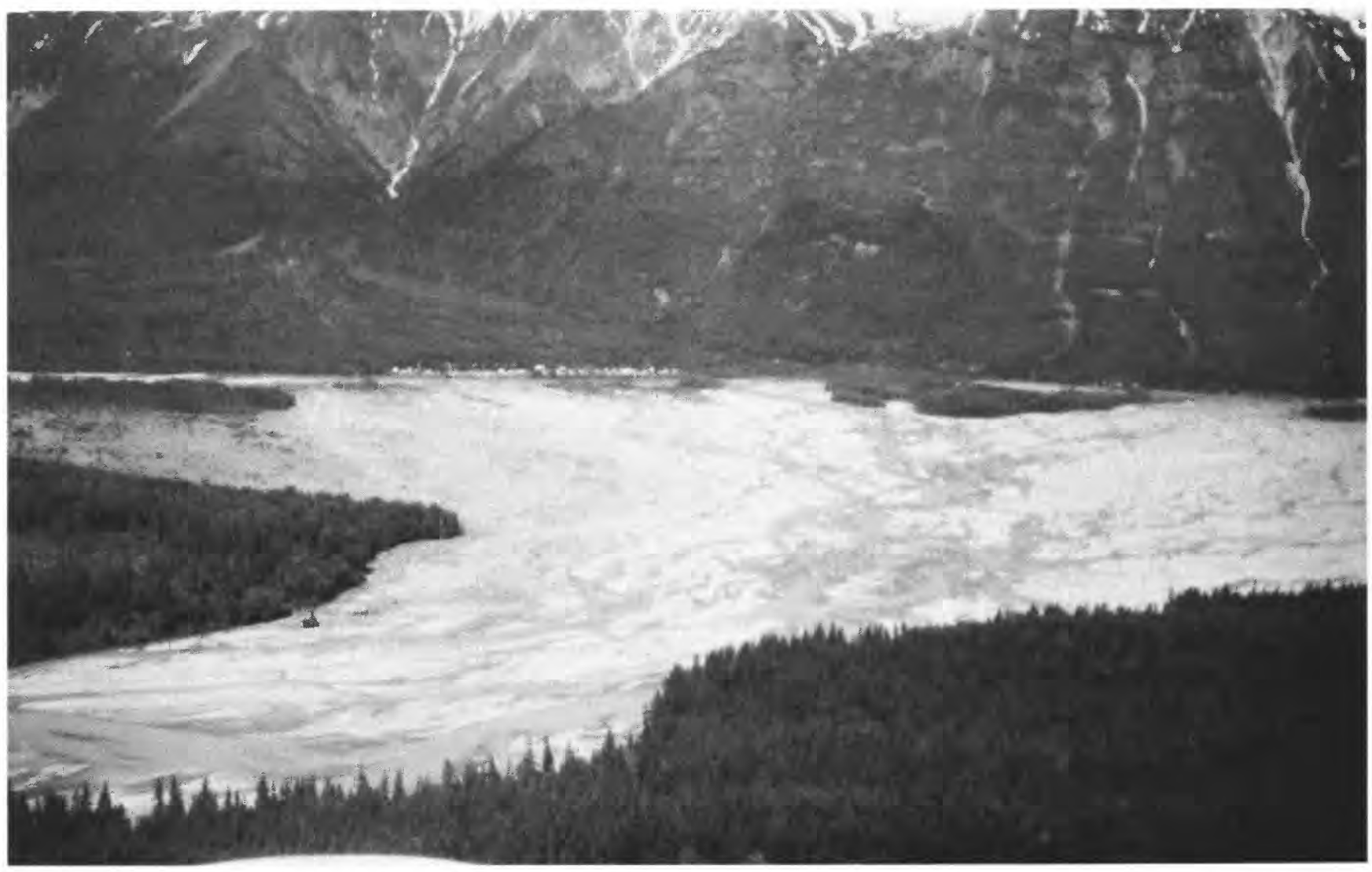

Figure 24. -- Tsirku alluvial fan, June 6, 1981. View northeast toward toe of fan and the Takshanuk Mountains shows multiple channels on the fan, and flat terrain. The village of Klukwan is at base of Takshanuk Mountains just left of the center of the photograph.

In order to check the validity of the simplified equations, J.D. Bredehoeft (U.S. Geological Survey, written commun., 1983) calculated the amount of ground water at $5{ }^{\circ} \mathrm{C}$ that would be required to maintain the 2-mile-1ong, 130-foot-wide lead between Wells, near the bridge spanning the Chilkat River, and site $\mathrm{C}-7$ near Klukwan. The calculations indicate that, on a cold cloudless winter night, 86 $\mathrm{ft}^{3} / \mathrm{s}$ of ground water would balance the heat loss to the atmosphere. This value does not differ greatly from the $59 \mathrm{ft}^{3} / \mathrm{s}$ ( $\left.1 \mathrm{~g} .12,21+38 \mathrm{ft}^{3} / \mathrm{s}=59 \mathrm{ft}^{3} / \mathrm{s}\right)$ of streamflow gain measured in this reach on Apri1 6, 1982.

\section{SUMMARY AND CONCLUSIONS}

Flow patterns of the Chilkat, Klehini, Tsirku, and Takhin Rivers, and selected smaller streams in the Chilkat Basin are typical of streams in the northern part of southeast Alaska. Peak flows occur during the summer, glacier-melt periods, and also during high precipitation events that are common in early fall. Lowest flows occur during winter and early spring. Water is of calctum bicarbonate composition except for a smal1, unnamed tributary (site C-8) on the Klukwan alluvial fan, which has a calcium sulfate water. 


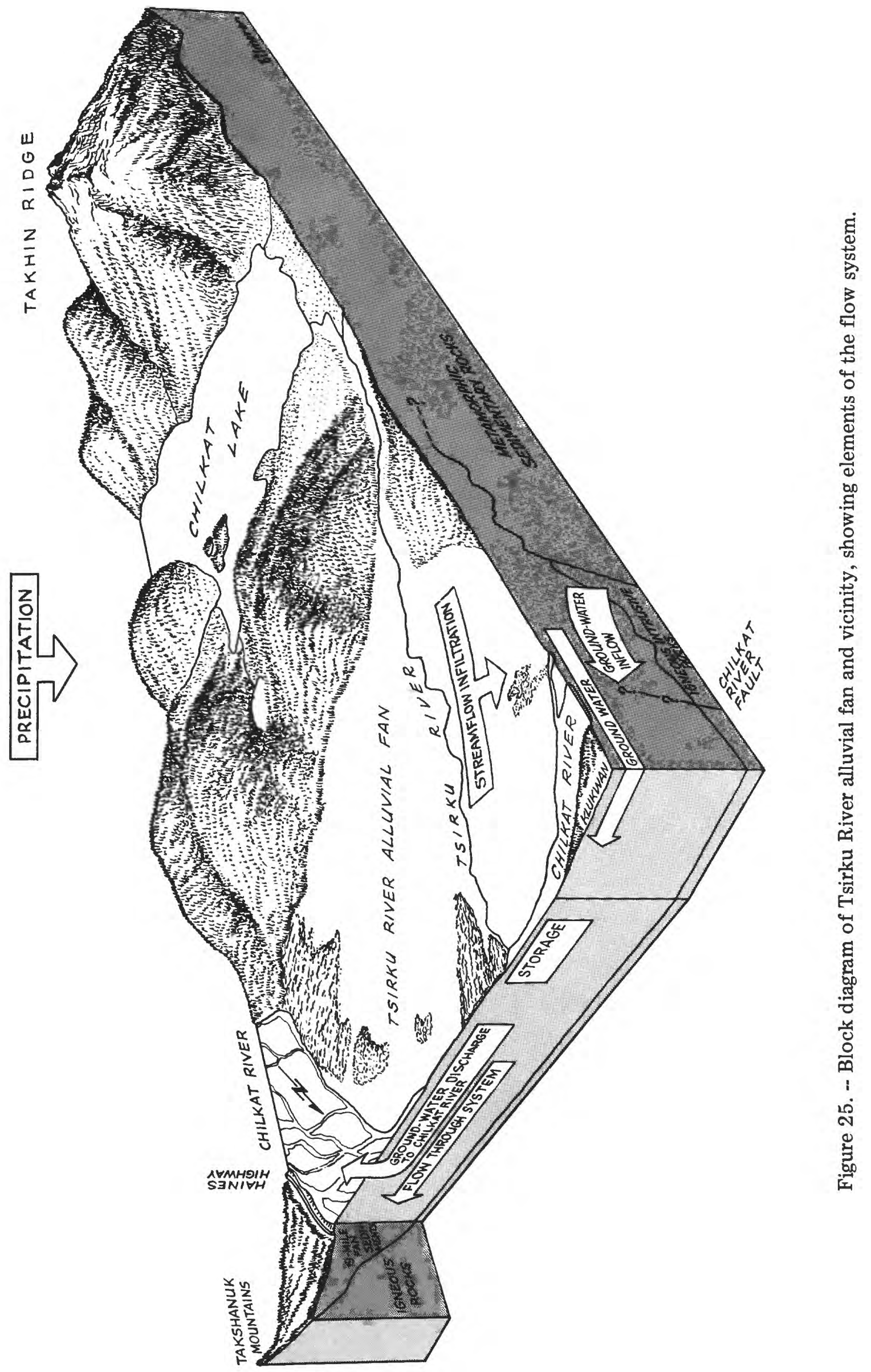


Chilkat Lake was thermally stratified during the August 18, 1981 samp1ing and was fairly well mixed during the March 15, 1983 sampling. The mixing is assumed to be a normal occurrence. The water in Chilkat Lake is a calcium bicarbonate type as are the tributaries that feed it. At a high stage in summer 1981, the Tsirku River discharged silt-laden water into Chilkat Lake. It is not known if such an influx of suspended sediment occurs periodically or to what extent it might alter the productivity of the lake.

The ground-water and surface-water systems of the Tsirku alluvial fan are closely linked. The principal source of recharge to the ground-water system is loss of water from stream channels that cross the fan surface. Water from the unconfined aquifer discharges into the Chilkat River near the toe of the fan at about $6^{\circ} \mathrm{C}$, allowing reaches of the river to remain open during winter.

During the winter the Little Salmon River and Clear Creek contribute about 81 percent of the flow of the Tsirku River at the head of the fan. The other 19 percent is outflow from Chilkat Lake.

Geochemical stable-1sotope analysis of water from a deep (260 ft) observation well at the toe of the Tsirku aljuvial fan suggests that water at this depth is derived from precipitation originating at high-altitude, interior locations. Shallower ground water (40-foot deep wells) is derived from a lower altitude, near-coastal enviroment.

Selsmic-refraction surveys indicate that the depth to bedrock at the axis of Chilkat Valley is more than $850 \mathrm{ft}$. The survey results were confirmed by test drilling $20 \mathrm{ft}$ into bedrock at the head of the Tsirku alluvial fan, and by comparison with an earlier gravimetric survev.

\section{REFERFNCES CITED}

Alaska Department of Highways, 1968, Bridge foundation report on the Chilkat River crossing: Project No. S-0961(7); Bridges 1162 and 1163,12 p.

Bishop, D.M., 1980, Chilkat valley streams which produce late fall and winter salmon runs: An exploratory study for the National Audubon Society, Environaid, Juneau, Alaska, $35 \mathrm{p}$.

Boeker, F.L., Hansen, A.J., and Meredith, R.A., 1980, Progress report: Chi1kat River cooperative bald eagle study: National Audubon Society, $53 \mathrm{p}$.

Brew, D.A., Loney, R.A., and Muffler, L.J.P., 1966, Tectonic history of Southeastern Alaska: In Canadian Institute of Mining and Metallurgy Special Volume No. 8, p. 149-170.

Fahnestock, R.K., 1967, Morphology and hydrology of a glaclal stream - White River, Mount Rainier, Washington: U.S. Geological Survey Professional Paper 42.2-A, $67 \mathrm{p}$.

Jobson, H.E., 1980, Thermal modeling of flow in the San Diego Aqueduct, California, and Its relation to evaporation: U.S. Geological Survey Professional Paper $1122,24 \mathrm{p}$.

Jobson, H.E., and Keefer, T.N., 1979, Modeling highly transient flow, mass, and heat transport in the Chattahoochee River near Atlanta, Georgia: U.S. Geological Survey Professional Paper $1136,41 \mathrm{p}$. 
Johnson, A., and Twenhofel, W.S., 1953, Potential industrial sites in the Lynn Canal area, Alaska: U.S. Geological Survey Circular 280, 17 p.

Mackevett, E.M., Robertson, E.C., and Winkler, G.R., 1974, Geology of the Skagway B-3 and B-4 quadrangles, southeastern Alaska; U.S. Geological Survey Professional Paper 832, 34 p., 1 plate.

McKenzie, G.D., and Goldthwait, R.P., 1971, Glacial history of the last eleven thousand years in Adams Inlet, southeastern Alaska: Geological Soclety of America Bulletin, v. 82, p. 1767-1782.

Muir, K.S., and Coplen, T.B., 1981, Tracing ground-water movement by using stable isotopes of oxygen and hydrogen, Upper Penitencla Creek alluvial fan, Santa Clara Valley, Calffornia: U.S. Geological Survey Water-Supply Paper 2075, 18 p.

Ovenshine, A.J., and Brew, D.A., 1972, Separation and history of the Chatham Strait fault, southeast Alaska, North America: International Geological Congress, 24th, Montreal, 1972, Proceedings, p. 245-254.

Riggs, H.C., 1969, Mean streamflow from discharge measurements: Bulletin of the International Association of Scientific Hydrology, v. XIV, no. 4, p. 95-110.

Scott, J.H., Tibbetts, B.L., and Burdich, R.G., 1972, Computer analysis of seismic refraction data: U.S. Bureau of Mines Report of Investigations 7595, $32 \mathrm{p}$.

Shirazi, M. A., and Seim, W. K., 1981, Stream system evaluation with emphasis on spawning habitat for salmonids: Water Resources Research, v. 17, no. 3, p. 592-594. 